\title{
Proteotoxicity and Neurodegenerative Diseases
}

\author{
Clara Ruz ${ }^{1}$, Jose Luis Alcantud ${ }^{1}$, Francisco Vives Montero ${ }^{1}$, Raquel Duran ${ }^{1}$ and \\ Sara Bandres-Ciga ${ }^{2, *}$ \\ 1 Instituto de Neurociencias Federico Olóriz, Centro de Investigación Biomédica, 18016 Granada, Spain; \\ clararuz@ugr.es (C.R.); jlalcantud@ugr.es (J.L.A.); fvives@ugr.es (F.V.M.); rduran@ugr.es (R.D.) \\ 2 Molecular Genetics Section, Laboratory of Neurogenetics, National Institute on Aging, National Institutes of \\ Health, Bethesda, MD 20892-3707, USA \\ * Correspondence: sara.bandresciga@nih.gov; Tel.: +1-301-451-6079
}

Received: 28 June 2020; Accepted: 4 August 2020; Published: 6 August 2020

\begin{abstract}
Neurodegenerative diseases are a major burden for our society, affecting millions of people worldwide. A main goal of past and current research is to enhance our understanding of the mechanisms underlying proteotoxicity, a common theme among these incurable and debilitating conditions. Cell proteome alteration is considered to be one of the main driving forces that triggers neurodegeneration, and unraveling the biological complexity behind the affected molecular pathways constitutes a daunting challenge. This review summarizes the current state on key processes that lead to cellular proteotoxicity in Alzheimer's disease, Parkinson's disease, Huntington's disease, and amyotrophic lateral sclerosis, providing a comprehensive landscape of recent literature. A foundational understanding of how proteotoxicity affects disease etiology and progression may provide essential insight towards potential targets amenable of therapeutic intervention.
\end{abstract}

Keywords: proteotoxicity; Alzheimer's disease; Parkinson's disease; Amyotrophic Lateral Sclerosis; Huntington disease

\section{Introduction}

Proteotoxicity, meaning impairment of cellular function as a result of protein misfolding or aggregation, is a major hallmark of a broad range of neurodegenerative diseases, including Alzheimer's disease (AD), Parkinson's disease (PD), amyotrophic lateral sclerosis (ALS), frontotemporal dementia (FTD), and Huntington's disease (HD), among others. A common denominator in the etiology of these diseases is that neuronal damage is frequently caused by abnormal aggregation and deposition of proteins in which altered specific molecular mechanisms lead to cell toxicity and degeneration.

Aging constitutes the main risk factor for neurodegenerative diseases [1] and proteotoxicity is an enhanced occurrence during the aging process. As we age, the ability of our organism to maintain protein homeostasis substantially decreases. Several studies have proven that the aging process actively suppresses our capacity to clear toxic protein aggregates, promoting the accumulation of these aggregates and initiating neurodegeneration late in life [2]. In general, aggregates of toxic proteins originate when soluble proteins gradually become insoluble filamentary polymers. These filamentous structures accumulate in the form of fibrils and end up depositing and aggregating in the nucleus, cytoplasm, or extracellular space of affected brain cells [3]. Eukaryotic cells have essential protein quality control (PQC) systems, including chaperones that safeguard proteins against aggregation, the ubiquitin-proteasome system (UPS) and the autophagy-lysosome system that act in the degradation of misfolded proteins. A decrease activity or saturation of these proteolytic systems results in neuronal impairment and cell death.

The fact that proteotoxicity is a shared emergent pattern among these diseases raises the question of whether common therapeutic interventions aimed at targeting dysregulated proteins by either 
blocking over aggregation or accelerating degradation may be applicable. Although it is widely known that similar molecular pathways altering cell viability through protein deposition cause these disorders (Table 1), the reality is that elimination of proteins in a way that toxicity can be mitigated is more complex than expected.

In this review, we explore underlying mechanisms that lead to proteotoxicity in four main neurodegenerative diseases in which this molecular signature plays a major role including HD, ALS, $\mathrm{PD}$, and $\mathrm{AD}$. In the current scenario, we summarize insights on the relationship between proteotoxicity and disease pathogenesis gained along the way, focusing on the distinct mechanisms underlying proteotoxicity in these diseases that have enhanced our needed understanding for the development of future and indispensable disease-modifying therapies. Uncovering how these biological processes trigger and promote disease progression certainly constitutes one of the main challenges in deciphering the pathophysiology of these debilitating conditions. 
Table 1. Proteotoxicity hallmarks across neurodegenerative diseases.

\begin{tabular}{|c|c|c|c|c|c|}
\hline $\begin{array}{l}\text { Neurodegenerative } \\
\text { Disease }\end{array}$ & $\begin{array}{l}\text { Protein } \\
\text { Aggregates }\end{array}$ & $\begin{array}{l}\text { IDR Protein } \\
\text { Structure }\end{array}$ & Species Location & Toxicity & References \\
\hline \multirow{8}{*}{ Huntington's disease } & \multirow{8}{*}{ Huntingtin } & \multirow{8}{*}{ PolyQ } & \multirow{8}{*}{$\begin{array}{l}\text { Intracellular (cytosolic } \\
\text { and nuclear) }\end{array}$} & Plasma-membrane integrity disruption & [4] \\
\hline & & & & Transcriptional dysregulation & [5] \\
\hline & & & & Reduced levels of neurotrophic factors as BDNF & {$[6]$} \\
\hline & & & & Impairment of protein degradation systems & {$[7,8]$} \\
\hline & & & & Mitochondrial dysfunction & {$[9,10]$} \\
\hline & & & & Reactive gliosis & [11] \\
\hline & & & & Neuroinflammation & [12] \\
\hline & & & & Cell death & {$[13]$} \\
\hline \multirow{18}{*}{$\begin{array}{l}\text { Amyotrophic Lateral } \\
\text { Sclerosis }\end{array}$} & \multirow{7}{*}{ TPD-43 } & \multirow{7}{*}{ C-Terminal Domain } & \multirow{18}{*}{ Cytoplasmic aggregate } & Affected mRNA splicing and RNA metabolism proteins & {$[14,15]$} \\
\hline & & & & Global protein synthesis inhibition & [16] \\
\hline & & & & Mitochondrial impairment & {$[17,18]$} \\
\hline & & & & Defective autophagy lysosomal pathway & [19-21] \\
\hline & & & & Endocytosis impairment & {$[22,23]$} \\
\hline & & & & Dysregulated metal ions (as zinc and manganese) & {$[24,25]$} \\
\hline & & & & Alteration in chromatin dynamics & [26] \\
\hline & \multirow{2}{*}{ FUS } & \multirow{2}{*}{ N-Terminal domain } & & Affected mRNA metabolism and DNA reparation & [27] \\
\hline & & & & Defects in Protein Quality Control (PQC) system & [28] \\
\hline & \multirow{6}{*}{ SOD-1 } & \multirow{6}{*}{$\begin{array}{c}22-30,55-95 \text { region } \\
121-143 \text { region }\end{array}$} & & Excitotoxity linked to glutamate transporter EAAT2 & {$[29,30]$} \\
\hline & & & & Excessive calcium influx & {$[29,30]$} \\
\hline & & & & Mitochondrial dysfunction & [31-33] \\
\hline & & & & Compromised axonal transport & [34-36] \\
\hline & & & & ROS cytotoxicity & [37] \\
\hline & & & & RNA species damaged & [38] \\
\hline & \multirow{2}{*}{ Ataxin-2 } & \multirow{2}{*}{ PolyQ tract } & & Stress response dysfunction & {$[39]$} \\
\hline & & & & Affected RNA metabolism & [40] \\
\hline & TBK-1 & TBK-1 & & Autophagy dysfunction & [41] \\
\hline
\end{tabular}


Table 1. Cont

\begin{tabular}{|c|c|c|c|c|c|}
\hline $\begin{array}{c}\text { Neurodegenerative } \\
\text { Disease }\end{array}$ & $\begin{array}{c}\text { Protein } \\
\text { Aggregates }\end{array}$ & $\begin{array}{l}\text { IDR Protein } \\
\text { Structure }\end{array}$ & Species Location & Toxicity & References \\
\hline Parkinson's disease & $\alpha$-Synuclein & C-terminal domain & $\begin{array}{l}\text { Intracellular LBs } \\
\text { formation, extracellular } \\
\text { and membrane }\end{array}$ & $\begin{array}{l}\text { Plasma-membrane integrity disruption } \\
\text { Synapse alteration } \\
\text { Perturbation in calcium homeostasis } \\
\text { Cytoskeleton dynamics altered } \\
\text { Protein degradation system dysfunction } \\
\text { Lysosomal impact } \\
\text { Mitochondrial dysfunction and ROS induction } \\
\text { Endoplasmic reticulum stress } \\
\text { Golgi transmission affected } \\
\text { Modified histone acetylation procedures } \\
\text { Apoptosis }\end{array}$ & $\begin{array}{c}{[42-45]} \\
{[46,47]} \\
{[48,49]} \\
{[50-52]} \\
{[53-55]} \\
{[55-57]} \\
{[58,59]} \\
{[59,60]} \\
{[61,62]} \\
{[63-65]} \\
{[66,67]} \\
\end{array}$ \\
\hline \multirow{2}{*}{ Alzheimer's disease } & Amyloid- $\beta$ & Amyloid- $\beta$ & Extracellular plaques & $\begin{array}{l}\text { Plasma-membrane alteration } \\
\text { Perturbed synaptic function and structure } \\
\text { Glial cells perturbation via mGluR } 5 \text { receptor } \\
\text { Altered calcium homeostasis } \\
\text { LTP inhibition in the CA1 region of the hippocampus } \\
\text { Oxidative stress disfunction }\end{array}$ & $\begin{array}{c}{[68,69]} \\
{[70-72]} \\
{[73]} \\
{[74]} \\
{[75,76]} \\
{[77,78]}\end{array}$ \\
\hline & Tau & N-terminal domain & $\begin{array}{c}\text { Intracellular } \\
\text { neurofibrillary tangles }\end{array}$ & $\begin{array}{l}\text { Telomerase dysfunction } \\
\text { Mitochondrial damage and ROS } \\
\text { Lipid peroxidation } \\
\text { Activated microglia leading to neuronal phagocytosis } \\
\text { Apoptosis }\end{array}$ & $\begin{array}{c}{[79,80]} \\
{[81,82]} \\
{[83]} \\
{[84,85]} \\
{[86]}\end{array}$ \\
\hline
\end{tabular}




\section{Proteotoxicity in Huntington Disease}

Huntington disease (HD) is a devastating neurodegenerative disorder caused by the expansion of a CAG trinucleotide repeat within the first exon of the HTT gene, which encodes huntingtin. The CAG repeat generates an expanded polyglutamine (polyQ) tract in the terminal region of the protein that misfolds to adopt a pathogenic conformation [87].

\subsection{Structure of the Huntingtin Protein}

Huntingtin is a large well-conserved protein of 3144 amino acids whose structure consists of many helical repeat units. The $\mathrm{N}$-terminal region has been extensively studied, as it contains the expandable polyQ tract. The polyQ tract is followed by a proline-rich domain that is thought to be critical for stabilizing the structure of the polyQ stretch as well as taking part in protein-protein interaction mechanisms [88]. The rest of the protein includes other functional motifs such as the elongation factor 3 , protein phosphatase $2 \mathrm{~A}$, and TOR1, which although they have been less well-characterized may act regulating the huntingtin function or localization [89]. In the population not affected by HD, the CAG sequence is repeated between 9 and 35 times, with an average median that ranges between 17 and 20 repeats [90]. When the CAG expansion exceeds 35 repeats proteotoxicity arises originating HD. Proteotoxicity is inversely proportional to the length of the CAG expansion, with juvenile onset being associated with about 75 or more repeats.

\subsection{Physiological Role of the Huntingtin Protein}

The huntingtin protein has long been considered having no clearly defined cellular function. Recent studies aimed at elucidating its role on disease have revealed that the protein acts controlling the anterograde and retrograde transport of organelles. Huntingtin mediates endocytosis, vesicle recycling, and endosomal trafficking. It acts regulating transport efficacy and directionality, including trafficking of precursor vesicles [91], endosomes and lysosomes [92,93], autophagosomes [94], and neurotrophic and neurotransmitter factors-containing vesicles $[95,96]$. The protein is also thought to coordinate cell division [97] and influence organogenesis and tissue maintenance by regulating metabolism. It is essential for embryonic development and the formation of the nervous system [98].

\subsection{Pathological Mechanisms of Huntingtin Aggregation}

An increase in the size of the CAG segment leads to the production of an abnormally long version of the huntingtin protein. The elongated protein is cut into smaller, toxic fragments that bind together and accumulate in neurons, disrupting their biological functions. It is still highly controversial whether the proteotoxicity process underlying HD is due to a gain of toxic function or a loss of function mechanism, or both. The fact that HD is an autosomal dominant disorder argues in favor of a gain of function of the protein. Mutant huntingtin is cleaved by proteases generating N-terminal fragments containing the abnormal polyQ tract, and it has been proven that longer polyQ stretches can promote their self-cleavage [99]. The shorter the fragments are the more toxicity is inferred in the cell where they may cause neuronal cell death by interfering with the transcription process in the nucleus [100]. Although a loss of function effect is also plausible, HD is unlikely to be caused by a straightforward loss-of-function mechanism. It was long thought that inactivation of one of the two wild-type huntingtin alleles was not a cause for HD phenotype [101]. However, animal models suggest that a loss-of-function of the wild-type huntingtin protein may contribute significantly to several components of disease pathology. Homozygous and heterozygous knockout models in mice and drosophila have shown neurodevelopmental defects and behavioral changes [102,103]. A loss of normal huntingtin function may have wider ranging impacts on cell physiology than previously thought, but this may be more observed in the aging process. Lower levels of wild-type huntingtin have been linked to proteasome and autophagy inhibition as well as vesicle transport impairment and 
signaling altered mechanisms related to the production and transport of the brain-derived neurotrophic factor (BDNF) [100].

\subsection{Therapeutic Insights}

Although there is currently no cure for HD, recent advances in genetic therapies hold great promise. Lowering the levels of the toxic mutant huntingtin by targeting either DNA or RNA and preventing protein expression while leaving the wild type copy untouched is currently the most prominent area of research in HD therapies. Recent research conducted in mice, patient-derived fibroblasts, and neurons revealed encouraging results using an engineered, synthetic transcription factor that achieved robust allele-selective targeting of endogenous mutant huntingtin. This approach provided a new method for the field to investigate the role of huntingtin in vivo [104]. Since huntingtin is involved in a wide range of biological functions, and a full knockdown of the gene is lethal in mice, maintaining some expression of the HTT gene is critical. Targeting gene regulation has gained a lot of attention in the last years since it is designed to enable precise and long-term repression of the selected gene following a single administration of an adeno-associate virus (AAV) that does not cut or modify the target DNA. This intervention is currently considered as one of the top potential therapeutic avenues since it prevents transcription of toxic huntingtin targeting all the potentially toxic downstream forms of the mutant protein. Another state of the art approach that has garnered a lot of attention recently is using antisense oligonucleotides (ASOs). A recent study showed promising results using ASO mediated suppression of the huntingtin (HTT) protein in the brains of adults with HD [105]. Using this approach, the first human safety trial was completed in 2017 and consisted of a drug developed to reduce the levels of the huntingtin protein in the nervous system, which successfully lowered levels of the toxic protein in participants. This therapy is currently under a major global phase 3 clinical trial in order to test the long-term safety and clinical efficacy as well as whether it slows disease progression or not. The final goal of these therapies is to delay or prevent neurodegeneration while function is still intact, giving gene carriers quality of life without impairment.

\section{Proteotoxicity in Amyotrophic Lateral Sclerosis}

Amyotrophic Lateral Sclerosis (ALS) is a fatal, neurodegenerative disease characterized by the death of both the upper and lower neurons of the spinal cord, responsible for controlling voluntary muscles [106].

A considerable number of proteins play a major role in ALS etiology, including Superoxide Dismutase 1 (SOD1), Fused in Sarcoma (FUS), Ataxin-2, and TANK-binding kinase 1 (TBK-1). In the current review we focus on the most relevant pathological hallmark: TAR DNA-binding protein 43 (TPD-43) [107]. TDP-43 is a highly conserved protein which belongs to the nuclear ribonucleoprotein family (hnRNP). It binds RNA and regulates mRNAs involved in the development of neurons [108].

\subsection{Structure of the TDP-43 Protein}

TDP-43 is a 414 amino acid protein predominantly localized in the nucleus but also in the cytoplasm and mitochondria. In ALS there is an increase in the cytoplasmic concentration via aggregation. The N-Terminal Domain (NTD) of the protein is responsible of TDP-43 dimerization. Research has pointed that this domain plays a major role on its physiological functions, being responsible for its aggregation [109]. TDP-43 also possesses two RNA Recognition Motifs (RRMs) with high specificity towards UG/TG-rich sequences of RNA/DNA molecules, given its role in several RNA processes. Since it has multiple locations, TDP-43 has different localization signals, such as: Nuclear Export Signal (NES), Nuclear Localization Signal (NLS), and Mitochondrial Localization Motifs (M1, M3, and M5). The C-Terminal Domain (CTD) is crucial for TDP-43 pathological behavior. This domain is aggregation-prone and contains phosphorylation targets as well as enzymatic caspase activity, which can produce highly cytotoxic C-terminal fragments [107]. 


\subsection{Physiological Functions of TDP-43}

TDP-43 takes part in plenty of molecular processes, such as RNA metabolism by regulating splicing, RNA maturation, stability and trafficking, transcriptional regulation by repressing transcription of some genes like $S P-10$, translational regulation by associating with $3^{\prime}$ UTR mRNA targets, protein stability and location, and response to stress. Regarding the former, TDP-43 can be recruited into stress granules so it stops specific mRNAs from being translated during the cellular stress response [110].

\subsection{Pathological Mechanisms of TDP-43 Aggregation}

TDP-43 has been identified in 97\% of ALS patients as aggregated protein in both the form of phosphorylated and ubiquitinated cytoplasmic inclusions. Albeit to a lesser extent, aggregates of acetylated and sumoylated TDP-43 have been also identified. Among all factors that influence its aggregation, post-translational modifications, C-terminal fragments and its prion-like behavior should be highlighted [111].

Post-translational modifications of TDP-43 change protein structure, localization, function, and therefore propensity to aggregate. Ubiquitination of TDP-43 has been shown to increase its nuclear depletion as a result of an incorrect degradation. Hence, its nuclear functions are affected by increased cytoplasmic accumulation which is highly toxic for the cell. Phosphorylation can also enhance its propensity to aggregate and being split into C-terminal fragments (CTF), which in turn leads to increased proteotoxicity [112]. These CTFs have a length between $25-35 \mathrm{kDa}$, some of them being more toxic than intact TDP-43. These motifs can also co-aggregate with other CTFs and TDP-43, thus increasing its toxic potential. The fact that different CTFs can have variable levels of toxicity and aggregation makes future studies necessary in order to elucidate the relationship between its structure and the cellular damage.

Symptoms of ALS are thought as a combination of several factors triggered by proteotoxicity. Loss of TDP-43 native functions causes failure in energy metabolism leading to protein metabolism, mitochondrial dysfunction, aggravated oxidative stress, alterations in several autophagy lysosomal processes, dysregulation of metal ion homeostasis (mainly zinc, copper, and manganese), impaired axonal outgrowth, or alteration in chromatin dynamics [107]. Additionally, it is thought that these events can be due to a toxic gain of function of aggregated TDP-43, since it is not an inert product. For example, aggregated cytoplasmic TDP-43 can sequester nuclear TDP-43 and other mRNAs proteins involved in transcriptional regulation [113].

\subsection{Prion-like Behavior of TDP-43 Aggregates}

Prions are misfolded proteins with toxic activity which can transmit their misfolded shape onto normal variants of the same protein. Prions are responsible of multiple degenerative diseases, such as Creutzfeldt-Jakob disease or kuru [107]. There are several studies suggesting that ALS might be a 'prion-like' disease because of the ability of the C-terminal region of TDP-43 to form stable $\beta$-sheets resembling amyloid-like fibrils. It seems that this structure is able to start a seeding mechanism similar to prions [113]. Despite this hypothesis, the mechanisms by which TDP-43 spreads into nearby cells remain unclear. Studies suggest that TDP-43 is transported through the axons, affecting nearby oligodendrocytes and neurons. This theory supports the idea of ALS spreading to neurons, just like prion diseases [112].

\subsection{Other Proteins Involved in Amyotrophic Lateral Sclerosis}

Besides TDP-43, it should be pointed out that FUS is a key proteotoxicity driver. Like TDP-43, FUS is an RNA binding protein (RBP) that regulates RNA metabolism, splicing, transcription, and transportation, and contributes to repair DNA damage. Its pathogenic properties are related to a mislocalization in the cytoplasm and a loss of function mechanism [114]. The structural domains exerting a major effect on ALS pathology seem to be located at the N-terminal prion-like domain, 
a portion of the glycine-rich region and the C-terminal nuclear localization signal (NLS), which are crucial for FUS mislocalization [27]. Just like TDP-43, such mislocalization leads to an aggregate that is able to sequester proteins and RNA gaining a toxic ability. Nevertheless, there is much controversy about the mechanisms driving this aggregation with some research suggesting that FUS loss of nuclear function is enough to develop toxicity [115]. Approximately 35\% of FUS-ALS patients develop the disease before the age of 40 years, and this aggressiveness is thought to be due to the synergy existing between FUS and other RBPs. In 2019, Marrone et al. demonstrated that FUS-ALS is linked to defects in the PQC system, and also that an inhibition of autophagy increases cytoplasmic FUS levels, leading to proteotoxicity. Inducing autophagy restored protein homeostasis showed improvement in FUS levels and cell survival. These autophagy inducer molecules could open a promising scenario in ALS disease-modifying therapies [28].

Another major contributor to proteotoxicity in ALS is SOD1. This enzyme is responsible of catalyzing the inactivation of superoxide into oxygen and hydrogen peroxide, being an indispensable antioxidant defense mechanism present in most of the cells. SOD1 is associated with an autosomal dominant form of ALS. Mutations in SOD1 destabilize its structure, which may lead to misfolding, oligomerization and formation of aggregates. Due to its ability to decrease chaperone and proteasome activity, these toxic aggregates are responsible for an insufficient clearance of intracellular proteins, which can bring aberrant protein-protein interactions. A lack of native structure cause aberrant redox chemistry which is toxic for the cells, leading to an increased amount of reactive oxygen species (ROS), capable of damaging other macromolecules [116]. Additional toxic features caused by SOD1 pathology include glutamate excitotoxicity due to a reduction in the astroglial glutamate transporter EAAT2 which leads to an excessive calcium influx, thus triggering destructive processes responsible for ALS pathology.

Furthermore, misfolded SOD1 can be localized to the outer membrane and matrix of the mitochondria, leading to malfunction and disruption of ATP production and energy homeostasis. Additionally, mutant SOD1 has been seen to be involved in loss of neurotrophic signaling and defective axonal transport in motor neurons [117]. Misfolded SOD1 can be secreted into the extracellular space and then sequestered by nearby cells where misfolded SOD1 is able to recruit additional misfolded proteins to enlarge itself [118].

Ataxin-2 is a member of the Lsm (Like-Sm) protein family. It is involved in a large number of functions including cellular stress responses and mRNA stability and translation. Ataxin-2 has a polyglutamine tract comprising 22-23 glutamines (Q) in the healthy population. An expansion of 27-33 Qs has been demonstrated to be linked to ALS [119]. Ataxin-2 links TDP-43 and its upregulation increases TDP-43 toxicity. Ataxin-2 is normally located in the cytoplasm of spinal cord neurons, but in ALS patients, its localization is altered, enhancing accumulation that eventually influences TDP-43 mislocalization under stress situations [40].

Finally, TANK-binding kinase 1 is composed of 4 domains: a kinase domain (KD), a ubiquitin-like domain (ULD) and two coiled-coil domains (CCD1 and CCD2). CCD1 is responsible for homodimerization of TBK-1, while CCD2 can bind and phosphorylate optineurin and p62, proteins known to be implicated in autophagy [120]. Several mutations in TBK1 cause protein truncation and loss of function, leading to a decrease in the protein ability to phosphorylate and bind optineurin and p62. Furthermore, other mutations can drop mRNA and protein levels, resulting in a lower activation of autophagy adaptors, leading to accumulation of toxic protein aggregates in motor neurons [41].

\subsection{Therapeutic Insights}

ALS is a complex and devastating disease with no diagnostic biomarkers or effective treatments to slow down its progression. Current strategies for intervention include preventing TDP-43 from aggregating or improving its clearance through a PQC system via a TDP-43 aggregation inhibitor molecule, such as acridine-imidazole derivative (AIM4) [121], 4-aminoquinoline derivatives [122], 
or a treatment with several copper complexes which has shown to inhibit TDP-43 accumulation and C-terminal fragment aggregation.

The use of a mutant chaperone Hsp104 has been shown to decrease TDP-43 toxicity, aggregation, and promote nuclear localization [123]. Furthermore, nuclear import receptors as karyopherin- $\beta 2$ have been proven to prevent aggregation of TDP-43 and other RNA-binding proteins, restoring their localization and functions [124].

Additionally, other ways of treating this disease include molecules targeting mechanisms leading to cellular dysfunction. Some examples are mexiletine that reduces neuronal hyperexcitability [125], edaravone, a free-radical scavenger which decreases oxidative stress [46], or rapamycin, an autophagy inducer that forms autophagosomes enhancing protein degradation, currently in a phase II clinical trial [126].

In the last years, several clinical trials have been carried out in order to test potential novel drugs for this terrible disease. Some examples are ropinirole hydrochloride, a molecule which targets abnormal TDP-43/FUS aggregation. It is a phase I/IIa randomized, double-blind, placebo-controlled, single-centre, open-label continuation trial with expected results by March 2021 [127]; tamoxifen, that showed ability to enhance autophagy and decrease TDP-43 aggregation in a small randomized double-blind trial whose results revealed a slight effect on attenuating disease progression for six months [128]; or arimoclomol, a heat shock protein co-inducer with neuroprotective properties in SOD1 related ALS, which was tested in a randomized, double-blind, placebo-controlled trial and lacked an important therapeutic benefit [129].

\section{Proteotoxicity in Parkinson's Disease}

Major advancements in genetics and neuropathology led to the identification of $\alpha$-synuclein as the major pathological hallmark of PD [130,131]. The SNCA gene encodes for a presynaptic protein called $\alpha$-synuclein, identified as the main component of amyloidogenic protein deposits known as Lewy bodies (LB) and Lewy neurites (LN) in PD [132]. Deleterious genetic variation in SNCA results in the accumulation and aggregation of misfolded $\alpha$-synuclein [133]. Although pathological mechanisms of PD are numerous and diverse, $\alpha$-synuclein proteotoxicity has been hypothesized to be one of the main contributors to the neurodegenerative process, spreading the pathological condition to neighboring cells like a prion-like disease [134]. In turn, these $\alpha$-synuclein aggregates can interact to promote disruption of protein homeostasis and thus interfere cell normal topography and physiology including stress formation on the endoplasmic reticulum (ER), mitochondrial dysfunction and defective neurotransmission, which if prolonged, could lead to neuronal death [58,135].

\subsection{Structure and Physiological Function of $\alpha$-Synuclein}

$\alpha$-synuclein is a small soluble protein (140 amino acid) highly expressed in the presynaptic zone of neuronal cells [136]. Unlike its pathological behavior, the normal function of this protein remains elusive. Some studies link it with synaptic transmission and vesicle trafficking, mitochondrial homeostasis, gene expression, protein phosphorylation, or even fatty acid binding $[137,138]$. $\alpha$-synuclein is differentiated into three main domains: the $\mathrm{N}$-terminal domain (amino acids 1-60); an hydrophobic central domain known as non-amyloid $\beta$-component domain or NAC (amino acids 61-95), which is associated to $\alpha$-synuclein aggregation in humans when $\beta$-sheet structure is acquired [139]; and the C-terminal region (amino acids 96-140) suggested to be involved in multiple functions, including self-protection of $\alpha$-synuclein from aggregation $[140,141]$. Except for some cases [142], native $\alpha$-synuclein is commonly found unfolded in a monomeric state, [143,144]. In contrast, there is no controversy under pathological conditions where $\alpha$-synuclein adopts a $\beta$-sheet amyloid conformation, promoting proteotoxic deposits. 


\subsection{Pathologic Mechanisms of $\alpha$-Synuclein Aggregation}

The aggregation process of $\alpha$-synuclein in vitro follows a similar pattern to other amyloid diseases. The oligomerization follows a nucleation-dependent pathway divided in three phases: the lag phase where the monomers form the aggregation nuclei; the elongation phase in which fibrils tend to grow exponentially, and finally the stationary phase where monomers leakage result in a decrease of growing rate [145-147]. Oligomers grow faster into the elongation phase, converted into protofibrils due to the monomer addition which conforms the amyloidogenic mature form. However, although the protein has mechanisms to protect itself from aggregation $[140,141]$, the reason why that occurs has not been identified yet. Thus, potential risk factors have been proposed to initiate/potentiate this procedure, such as genetic mutations $[148,149]$, environmental factors as iron exposure and pesticides and dietary aspects [150].

$\alpha$-synuclein toxicity follows the prion-like hypothesis where the misfolded protein spreads cell to cell via endocytosis transmission. Subsequent to $\alpha$-synuclein aggregation, anomalous oligomers are released from cells. Exogenous $\alpha$-synuclein fibrils can invade inside cells, seeding them into recipient cells, and induce its propagation cell to cell by originating a new cycle of endocytosis. This event would finally end inducing new LB-like inclusions [67]. The presence of $\alpha$-synuclein deposits, according to similar mechanisms in other neurodegenerative diseases, suggests that the main link between $\alpha$-synuclein and PD pathology is the gain of function hypothesis. In this direction, we briefly recap the main proteotoxicity effects of $\alpha$-synuclein in PD pathogenesis.

Post-translational modification including phosphorylation, ubiquitination, and glycosylation, plays an essential role in protein structure, modification, and function. Disruption of these processes has been linked to an intricate cellular proteostasis state within the cell. Accordingly, altered hyper phosphorylation was found in $\alpha$-synuclein site Ser129 in LBs. Therefore, phosphorylation of Ser129 has evidenced to facilitate cytotoxic transport to the nucleus, being capable of interacting with histones inducing neurotoxicity [45].

In addition, $\alpha$-synuclein toxicity within the nucleus may implicate the inhibition of histone acetylation, promoting neuronal disruption and cell death [65,151]. Furthermore, amyloidogenic $\alpha$-synuclein can modify lipid permeabilization, thus altering the structural components of the cell. One potential hypothesis suggests that these oligomers penetrate the cell membranes and reorganize lipid environment, stimulating the flux of surrounding molecules [152]. An alternative theory supports that oligomers could be fused with the membranes acting as an amyloid pore or channel $[153,154]$. These events have been suggested to enhance extracellular calcium flux within cells so that could be responsible for the cell death of dopaminergic neurons in PD. In a similar way, $\alpha$-synuclein aggregates disrupt the main protein clearance systems within the cell and therefore mitochondrial function [155]. The autophagy lysosomal pathway (ALP) and the UPS have been associated with PD pathology. In the last decade, genetic perturbation in several genes including LRRK2, SNCA, LAMP3, GBA, and ATP13A2 affecting lysosomal activity have been elucidated $[156,157]$. In vitro models showed that pathologic $\alpha$-synuclein blocks macroautophagy by binding key proteins, such as the lysosomal LAMP2 receptor in ALP or the 20S component in UPS [54,55]. Although further studies are needed, these events suggest that $\alpha$-synuclein drives proteotoxicity by disrupting protein clearance of substrates. Consequently, accumulation of several substrates in addition to toxic oligomers within the cytosol, rise mitochondrial dysregulation associated with complex I activity, which is impaired in the brain tissue of PD patients and in vitro [158].

Despite SNCA being the major genetic contributor to PD etiology, genetic mutations in PINK1 or DJ1 in mendelian forms of PD result in a mitochondrial perturbation due to a toxic gain of function in the mutated proteins [59]. PINK1 is a kinase protein involved in several events within the mitochondria, including oxidative phosphorylation or mitophagy. According to the proposed mechanisms above mentioned, $\alpha$-synuclein toxic effects may lead to disrupted mitochondrial dynamics altering electronic potential and facilitating mitochondrial fragmentation, dysfunctional mitophagy or increased mitochondrial ROS levels. Multiple other cellular pathways are affected by $\alpha$-synuclein, as ER 
stress promotion which in turn promotes ER-Golgi transport dysfunction and Golgi fragmentation [60,61]. Taking this together, $\alpha$-synuclein toxicity drives the main pathologic events in PD. However, how $\alpha$-synuclein triggers those pathological events in PD, being either cause or consequence of it, remains unclear.

\subsection{Therapeutic Insights}

Since protein aggregation is responsible for neurodegeneration, there is now emerging research towards restoring proteostasis through stimulation of the PQC system. Within the wide range of experimental studies, one of the most promising treatments is ambroxol, a small molecule chaperone that crosses the blood-brain barrier and helps defective GBA protein refold and traffic correctly to lysosomes. In a recent open-label clinical trial of $17 \mathrm{PD}$ patients both with and without $G B A$ mutations, ambroxol increased GBA activity and modulated $\alpha$-synuclein levels in cerebrospinal fluid [159]. Although a larger study is required, ambroxol therapy seems to bring hopeful results. Regarding immunotherapy, there are several studies in preliminary stages of clinical investigation [160]. The monoclonal antibody PRX002, designed to preferentially target soluble and insoluble aggregated forms of a-synuclein, significantly reduced free serum $\alpha$-synuclein levels in humans, [161] being safe and well tolerated by participants after intravenous infusions of multiple ascending doses [162]. BIIB054, another anti a-synuclein antibody, has demonstrated an acceptable safety among participants, and has been currently enrolled in novel trials to examine its capacity of a-synuclein clearance to cerebrospinal fluid [163].

\section{Proteotoxicity in Alzheimer's Disease}

Alzheimer's disease (AD) is a neurodegenerative disease characterized by the accumulation of extracellular amyloid- $\beta(A \beta)$ plaques and intracellular neurofibrillary tangles of hyperphosphorylated tau proteins leading to neuronal loss and cerebral atrophy. AD is the main cause of dementia and accounts for up to $60-80 \%$ of all dementia diagnoses [164]. Moreover, the number of new cases with AD increases with age, doubling in prevalence every 5 years after age 65 [165]. Although the vast majority of AD cases are considered sporadic ( $>90 \%)$, they are thought to be influenced by a combination of genetic and environmental factors. Mendelian forms linked to an autosomal dominant pattern of inheritance, are caused by mutations in three genes- amyloid precursor protein $(A P P)$, presenilin 1 (PSEN1), and presenilin 2 (PSEN2), representing less than 1\% of AD cases [166]. Clinically, AD is defined by progressive cognitive decline enough to affect abilities to work and/or to complete basic daily activities. Behavioral change, impaired mobility, hallucinations and seizures also may emerge with the disease progression. Death is on average 8.5 years from symptoms presentation [167].

\subsection{Structure of the Amyloid- $\beta$ Peptide}

Amyloid- $\beta$ (A $\beta$ ) peptide is a $39-42$ residue protein generated from the sequential processing of the transmembrane amyloid precursor protein (APP) by $\beta$ - and $\gamma$-secretases. First, APP is cleaved by $\beta$-secretase producing the membrane-bound fragment $C 99$, which then is subjected to a secondary cleavage by $\gamma$-secretase leading to the release of soluble $A \beta$ peptides [168]. The most prevalent forms are peptides with $40(\mathrm{~A} \beta 1-40)$ and $42(\mathrm{~A} \beta 1-42)$ amino acid residues, the latter being considered as the more toxic species that contributes to the amyloid fibril formation. These species seem to play a key role in amyloid nucleation. A large number of experimental studies have focused on identifying the on-pathway intermediaries responsible for fibril formation. Structural analyses by atomic resolution of A $\beta 1-42$ amyloid fibrils show that the fibril core would be composed of a dimer of $A \beta 42$ molecules. They seem to be arranged resulting in two hydrophobic clusters sited at the end of the chain by a salt bridge [169]. Furthermore, it is likely that a hydrophobic environment favors the formation of prefibrillar aggregates based in intermolecular $\beta$-sheet structures, acting as precursors for the amyloid nucleation [170,171]. Apart from these arrangements, the presence of charged residues in the A $\beta$ $\mathrm{N}$-terminal region influences directly the amyloidogenesis process through their interactions and 
binding with the membrane lipid bilayer. The accumulation of $\mathrm{A} \beta$ peptides on membranes would trigger a loss of biophysical properties and subsequently fragmentation [172,173].

\subsection{Physiological Role of the Amyloid Precursor Protein (APP) and A Peptide}

Despite that APP has been largely studied as a precursor of $\mathrm{A} \beta$ and a key peptide in the pathogenesis of $\mathrm{AD}$, its physiological functions are not still completely understood. Within the cell, APP is mainly located in the somatodendritic and axonal compartments, and highly abundant in the synaptic terminals. Once it is synthesized in the endoplasmic reticulum, APP matures through the secretory pathway until it reaches the cell surface [174]. Here, it can be cleaved by secretases following two canonical processing pathways, including the amyloidogenic and non-amyloidogenic pathways. The way in which APP is finally processed seems to be linked to its cell localization, thus APP accumulated in the cell surface promotes non-amyloidogenic processing whereas APP stored in intracellular compartments does amyloidogenic processing [175]. Even so, the APP catalytic processing is highly regulated in the cell, and under physiological conditions the non-amyloidogenic pathway is the predominant route. Based on recent investigations, APP is considered as a multimodal protein that can regulate biological processes ranging from transcriptional regulation to synaptic functions. This variety of functions is mediated by cell surface APP or by one its proteolytic fragments [176]. The structural features of APP, which mainly include two heparin-binding domains within the E1 and E2 domains in the extracellular region, strengthens the idea that APP may act as a cell surface receptor. These two domains, with different binding affinities for ligands, would allow the receptor to initiate more rapid and selective intracellular signaling cascade. Moreover, its transmembrane domain could serve as guide signals to carry out the protein transport from endoplasmic reticulum to plasma membrane [177]. As mentioned above, the high expression of APP in synaptic terminals also suggests a role for this protein in synaptic plasticity, learning, and memory. Secreted APP (sAPP) has been proposed to facilitate long-term potentiation and to increase memory in rats and transgenic models of AD [178]. sAPP induces several intracellular signaling cascades that support synaptic plasticity, however, its main receptor target remains unclear. Recently, the gamma-aminobutyric acid type B receptor subunit 1a (GABABR1a) has been identified as synaptic receptor for sAPP. sAPP-GABABR1a binding suppresses synaptic vesicle release and thus modulates synaptic plasticity and neurotransmission [179]. Furthermore, $A \beta$ peptides can exert an opposite effect on synaptic plasticity and memory depending on its concentration. It has been reported that high levels of oligomeric $A \beta 42$ in mouse hippocampal neurons induce synaptic dysfunction leading to memory impairment in AD. However, when picomolar concentrations are used, they promote long-term potentiation (LTP) and memory [180,181].

\subsection{Pathological Mechanisms of $\beta$-Amyloid Peptide Aggregation}

Although the pathogenesis of $\mathrm{AD}$ is quite complex, there is solid evidence to support that $\mathrm{A} \beta$ plays a central role. A $\beta 42$ underlies aggregation when monomer concentration exceeds a critical concentration. This process would act as primary nucleation pathway for the formation of oligomers, and these, in turn, might serve as basis for a slow aggregation into fibrils [182]. Recent studies show a correlation between soluble $A \beta$ oligomer levels and disease severity, highlighting them as the main toxic species [75,183]. Extracellular $A \beta$ oligomers can be formed in the presence of GM1 ganglioside on the cell membrane. These seem to induce neuronal cell death mediated by nerve growth factor (NGF) receptors. Binding of $A \beta$ oligomers to other receptors, such as cellular prion protein and NMDA-type glutamate receptor, causes failure of the neuron signal-transduction pathways related to synaptic function and abnormal calcium homeostasis, respectively. Moreover, $A \beta$ oligomers can induce the loss of insulin receptor from the neuronal surface and impair kinase activity related to long-term potentiation [184]. At the intracellular level, A $\beta$ oligomers inhibit proteasome function resulting in pathological accumulation of $A \beta$ and Tau proteins and subsequently in cell death. The autophagy-lysosome pathway is also impaired. $A \beta$ can accumulate in lysosome and 
alter its membrane permeability, occasioning the $\mathrm{A} \beta$ release to the cytosolic compartment $[185,186]$. $\mathrm{A} \beta$-induced mitochondrial dysfunction has been extensively associated to AD pathology. This toxic effect would be mediated by a reduction in the electron transport chain enzymatic activities $[186,187]$.

\subsection{Tau and Phosphorylated Tau}

Tau is clearly a determinant protein in the neurodegenerative process of AD [188]. The close association that exists between disease severity and tau load which is higher than those found in $\mathrm{A} \beta$, encourages us to think in a primary role for Tau within the pathological events that occur in AD. Emerging investigations support the idea that $A \beta$ initiates the onset of AD while Tau mediates the subsequent functional deficits at an early stage of the disease. Tau comprises of four domains: N-terminal domain; proline-rich domain, which is located in the central region of the protein; microtubule-binding domain (MBD), which is the region responsible for binding of Tau with microtubules (MTs); and C-terminal domain. The MBD includes four repeats (4R isoform) or three repeats ( $3 \mathrm{R}$ isoform) of approximately a sequence of 32 amino acid residues, as a consequence of alternative splicing in the molecule [189]. These two isoforms are maintained in equilibrium in adult human brains, being essential for a normal function of the protein. One of the widely known roles for Tau is to promote MTs assembly and stability. Interaction of Tau with MTs depends on its phosphorylation/dephosphorylation state by activity of kinases and phosphatases, respectively, binding to MTs when it is dephosphorylated, and separating from them when it is phosphorylated [190]. The interplay between Tau and motor proteins allows the correct axonal transport in the brain, and regulates the development of axonal neurites [191]. Moreover, Tau is also distributed in dendrites at the postsynaptic compartment, suggesting an important role in regulating normal synaptic function [192]. Other recent studies describe a protective role for Tau in the damage of neuronal DNA and RNA by oxidative stress [193], as well as its ability to regulate brain insulin signaling [194]. Despite its low tendency to accumulation, certain post-translational modifications in Tau such as hyperphosphorylation, promote a progressive self-assembly into soluble oligomeric forms and insoluble tangles of filaments [195]. Although the identification of Tau species responsible for neurotoxicity is still under investigation, it is known that pathological aggregation of this protein acts endangering the physiological functions above mentioned and subsequently cell survival $[70,196]$.

\subsection{Therapeutic Insights}

Despite its high prevalence, there is currently no cure or available treatment to significantly modify the progress of the disease. A substantial part of treatments under clinical trial investigation is based on immunotherapy, in which most strategies are directed to $A \beta$ targeting. Whilst it has shown promising results in animal models of $\mathrm{AD}$, human trials are producing disappointing outcomes. There are more than forty immunotherapies (comprising active and passive) registered in the database Alzforum.org (https://www.alzforum.org/therapeutics). However, many of them are not making progress due to unsuccessful clinical efficacy and major safety problems. At present only four have reached Phase 3 of clinical research. Preliminary results after treatment with aducanumab (monoclonal antibody that selectively reacts with $A \beta$ aggregates) have showed a reduction of brain $A \beta$ plaques together with a slowing of clinical decline in patients with prodromal or mild AD [197]. Likewise, administration of gantenerumab (another monoclonal antibody that binds with high affinity to aggregates $A \beta$ species) has resulted in significant $A \beta$ plaques removal at 104 weeks of treatment in patients with prodromal to moderate AD dementia [198]. The ongoing analyses augur to provide valuable information about clinical benefits. Apart from immunotherapy, other anti-amyloid drugs such as $\beta-\gamma$-secretase inhibitors and $\gamma$-secretase modulators are being evaluated. For instance, tarenflurbil has been reported to be a selective A $\beta 42$-lowering agent and also seems to protect from cytotoxicity associated with exposure to $A \beta 42$ in cultured neuronal cells $[199,200]$. Furthermore, there are therapeutic approaches that are focused on other pathological events, such as synaptic loss, autophagy impairment, mitochondrial dysfunction, and neuroinflammation [201]. However, with the exception of the acetylcholinesterase 
inhibitors already approved (Donepezil, Rivastigmine, or Galantamine, among others) the majority of treatments are not showing significant clinical benefits or are still in preclinical stages. The complex nature of this disease possibly determines the failure of many therapies directed to one single target. The development of therapies focused on multiple targets might be the base of future strategies.

\section{Concluding Remarks and Future Directions}

Neurodegenerative diseases are a great burden for our health system. This review has examined the advances that have been made in understanding how molecular mechanisms get disrupted by proteotoxicity causing cell death in these diseases. We have discussed how disease arises as a result of neural cells not being capable of maintaining the stability of its proteome through adequate folding and degradation of aberrant proteins. Despite efforts, our knowledge of disease aetiology is still limited and so far it is unknown whether aggregation is a cause or a protective consequence for disease. This review supports the notion that although shared features driving proteotoxicity are implicated in these four neurodegenerative diseases including protein misfolding and aggregation, protein propagation, and proteostasis impairment, the current literature suggests that the proteins and aggregates implicated in each of these diseases as well as the genetic basis driving their pathology are not shared but disease specific. Additional evidence to unravel the coexistence of proteins and their interactions among these neurodegenerative diseases is required. Along the way we have learnt that therapeutic strategies designed to prevent or stop disease progression will not be possible without critically re-establishing perturbations in protein quality control. Increasing proteasome activity, enhancing cellular PQC mechanisms by upregulation of chaperones and clearance cascade pathways, as well as controlling the capability of misfolded proteins to propagate to nearby cells, are key to avoid progressive neuronal degeneration. As highlighted in this review, successful treatment opportunities will not be sufficient with single-target approaches aimed to specifically tag toxic protein species. The new era for the treatment of proteinopathies holds promise while we continue unraveling the pathological processes underlying these complex diseases.

Author Contributions: Initial manuscript preparation: C.R., J.L.A., S.B.-C., R.D. Manuscript editing and commentary: S.B.-C., F.V.M. All authors have read and agreed to the published version of the manuscript.

Funding: This research was supported in part by the Intramural Research Program of the National Institutes of Health (National Institute on Aging) 1ZIA-NS003154.

Acknowledgments: Funding agencies. C. Ruz held a predoctoral fellowship (FPU14/03473, MECD, Spain) from the Spanish Ministry of Education and Science.

Conflicts of Interest: The authors declare no conflict of interest.

\section{Abbreviations}

$\begin{array}{ll}\text { AD } & \text { Alzheimer's disease } \\ \text { PD } & \text { Parkinson's disease } \\ \text { ALS } & \text { Amyotrophic lateral sclerosis } \\ \text { FTD } & \text { Frontotemporal dementia } \\ \text { HD } & \text { Huntington's disease } \\ \text { PQC } & \text { Protein quality control } \\ \text { UPS } & \text { Ubiquitin-proteasome system } \\ \text { polyQ } & \text { Polyglutamine } \\ \text { BDNF } & \text { Brain-derived neurotrophic factor } \\ \text { AAV } & \text { Adeno-associate virus } \\ \text { ASOs. } & \text { Antisense oligonucleotides } \\ \text { SOD1 } & \text { Superoxide Dismutase 1 } \\ \text { FUS } & \text { Fused in Sarcoma }\end{array}$




$\begin{array}{ll}\text { TBK-1 } & \text { TANK-binding kinase 1 } \\ \text { hnRNP } & \text { Ribonucleoprotein family } \\ \text { TPD-43 } & \text { TAR DNA-binding protein 43 } \\ \text { NTD } & \text { N-Terminal Domain } \\ \text { RRMs } & \text { RNA Recognition Motifs } \\ \text { NES } & \text { Nuclear Export Signal } \\ \text { NLS } & \text { Nuclear Localization Signal } \\ \text { CTD } & \text { C-Terminal Domain } \\ \text { CTF } & \text { C-terminal fragments } \\ \text { RBP } & \text { RNA binding protein } \\ \text { ROS } & \text { Reactive oxygen species } \\ \text { Q } & \text { Glutamines } \\ \text { NLS } & \text { C-terminal nuclear localization signal } \\ \text { CTF } & \text { C-terminal fragments } \\ \text { RBP } & \text { RNA binding protein } \\ \text { KD } & \text { Kinase domain } \\ \text { ULD } & \text { Ubiquitin-like domain } \\ \text { CCD1 and CCD2 } & \text { Two coiled-coil domains } \\ \text { AIM4 } & \text { Acridine-imidazole derivative } \\ \text { LB } & \text { Lewy bodies } \\ \text { LN } & \text { Lewy neurites } \\ \text { ER } & \text { Endoplasmic reticulum } \\ \text { ALP } & \text { Autophagy lysosomal pathway } \\ \text { AB } & \text { Amyloid-beta } \\ \text { APP } & \text { Amyloid precursor protein } \\ \text { PSEN1 } & \text { Presenilin 1 } \\ \text { PSEN2 } & \text { Presenilin 2 } \\ \text { APP } & \text { Amyloid precursor protein } \\ \text { SAPP } & \text { Secreted APP } \\ \text { GABABR1a } & \text { Gamma-aminobutyric acid type B receptor subunit 1a } \\ \text { LTP } & \text { Promote long-term potentiation } \\ \text { NGF } & \text { Nerve growth factor } \\ \text { MDR } & \end{array}$

\section{References}

1. Hou, Y.; Dan, X.; Babbar, M.; Wei, Y.; Hasselbalch, S.G.; Croteau, D.L.; Bohr, V.A. Ageing as a risk factor for neurodegenerative disease. Nat. Rev. Neurol. 2019, 15, 565-581. [CrossRef] [PubMed]

2. Sweeney, P.; Park, H.; Baumann, M.; Dunlop, J.; Frydman, J.; Kopito, R.; McCampbell, A.; Leblanc, G.; Venkateswaran, A.; Nurmi, A.; et al. Protein misfolding in neurodegenerative diseases: Implications and strategies. Transl. Neurodegener. 2017, 6, 6. [CrossRef] [PubMed]

3. Kumar, V.; Sami, N.; Kashav, T.; Islam, A.; Ahmad, F.; Hassan, M.I. Protein aggregation and neurodegenerative diseases: From theory to therapy. Eur. J. Med. Chem. 2016, 124, 1105-1120. [CrossRef] [PubMed]

4. Sameni, S.; Malacrida, L.; Tan, Z.; Digman, M.A. Alteration in Fluidity of Cell Plasma Membrane in Huntington Disease Revealed by Spectral Phasor Analysis. Sci. Rep. 2018, 8, 734. [CrossRef] [PubMed]

5. Bae, B.-I.; Xu, H.; Igarashi, S.; Fujimuro, M.; Agrawal, N.; Taya, Y.; Hayward, S.D.; Moran, T.H.; Montell, C.; Ross, C.A.; et al. p53 mediates cellular dysfunction and behavioral abnormalities in Huntington's disease. Neuron 2005, 47, 29-41. [CrossRef] [PubMed]

6. Zuccato, C.; Marullo, M.; Vitali, B.; Tarditi, A.; Mariotti, C.; Valenza, M.; Lahiri, N.; Wild, E.J.; Sassone, J.; Ciammola, A.; et al. Brain-derived neurotrophic factor in patients with Huntington's disease. PLoS ONE 2011, 6, e22966. [CrossRef] [PubMed]

7. Ravikumar, B.; Duden, R.; Rubinsztein, D.C. Aggregate-prone proteins with polyglutamine and polyalanine expansions are degraded by autophagy. Hum. Mol. Genet. 2002, 11, 1107-1117. [CrossRef] 
8. Holmberg, C.I.; Staniszewski, K.E.; Mensah, K.N.; Matouschek, A.; Morimoto, R.I. Inefficient degradation of truncated polyglutamine proteins by the proteasome. EMBO J. 2004, 23, 4307-4318. [CrossRef]

9. Kuhl, D.E.; Metter, E.J.; Riege, W.H.; Markham, C.H. Patterns of cerebral glucose utilization in Parkinson's disease and Huntington's disease. Ann. Neurol. 1984, 15, S119-S125. [CrossRef]

10. Kuwert, T.; Lange, H.W.; Langen, K.J.; Herzog, H.; Aulich, A.; Feinendegen, L.E. Cortical and subcortical glucose consumption measured by PET in patients with Huntington's disease. Brain 1990, 113, 1405-1423. [CrossRef]

11. Crotti, A.; Benner, C.; Kerman, B.E.; Gosselin, D.; Lagier-Tourenne, C.; Zuccato, C.; Cattaneo, E.; Gage, F.H.; Cleveland, D.W.; Glass, C.K. Mutant Huntingtin promotes autonomous microglia activation via myeloid lineage-determining factors. Nat. Neurosci. 2014, 17, 513-521. [CrossRef] [PubMed]

12. Ide, K.; Nukina, N.; Masuda, N.; Goto, J.; Kanazawa, I. Abnormal gene product identified in Huntington's disease lymphocytes and brain. Biochem. Biophys. Res. Commun. 1995, 209, 1119-1125. [CrossRef] [PubMed]

13. Wellington, C.L.; Ellerby, L.M.; Gutekunst, C.-A.; Rogers, D.; Warby, S.; Graham, R.K.; Loubser, O.; Van Raamsdonk, J.; Singaraja, R.; Yang, Y.-Z.; et al. Caspase cleavage of mutant huntingtin precedes neurodegeneration in Huntington's disease. J. Neurosci. 2002, 22, 7862-7872. [CrossRef] [PubMed]

14. Highley, J.R.; Kirby, J.; Jansweijer, J.A.; Webb, P.S.; Hewamadduma, C.A.; Heath, P.R.; Higginbottom, A.; Raman, R.; Ferraiuolo, L.; Cooper-Knock, J.; et al. Loss of nuclear TDP-43 in amyotrophic lateral sclerosis (ALS) causes altered expression of splicing machinery and widespread dysregulation of RNA splicing in motor neurones. Neuropathol. Appl. Neurobiol. 2014, 40, 670-685. [CrossRef] [PubMed]

15. Arnold, E.S.; Ling, S.-C.; Huelga, S.C.; Lagier-Tourenne, C.; Polymenidou, M.; Ditsworth, D.; Kordasiewicz, H.B.; McAlonis-Downes, M.; Platoshyn, O.; Parone, P.A.; et al. ALS-linked TDP-43 mutations produce aberrant RNA splicing and adult-onset motor neuron disease without aggregation or loss of nuclear TDP-43. Proc. Natl. Acad. Sci. USA 2013, 110, E736-E745. [CrossRef]

16. Russo, A.; Scardigli, R.; La Regina, F.; Murray, M.E.; Romano, N.; Dickson, D.W.; Wolozin, B.; Cattaneo, A.; Ceci, M. Increased cytoplasmic TDP-43 reduces global protein synthesis by interacting with RACK1 on polyribosomes. Hum. Mol. Genet. 2017, 26, 1407-1418. [CrossRef]

17. Wang, W.; Li, L.; Lin, W.-L.; Dickson, D.W.; Petrucelli, L.; Zhang, T.; Wang, X. The ALS disease-associated mutant TDP-43 impairs mitochondrial dynamics and function in motor neurons. Hum. Mol. Genet. 2013, 22, 4706-4719. [CrossRef]

18. Stribl, C.; Samara, A.; Trümbach, D.; Peis, R.; Neumann, M.; Fuchs, H.; Gailus-Durner, V.; Hrabě de Angelis, M.; Rathkolb, B.; Wolf, E.; et al. Mitochondrial dysfunction and decrease in body weight of a transgenic knock-in mouse model for TDP-43. J. Biol. Chem. 2014, 289, 10769-10784. [CrossRef]

19. Xia, Q.; Wang, H.; Hao, Z.; Fu, C.; Hu, Q.; Gao, F.; Ren, H.; Chen, D.; Han, J.; Ying, Z.; et al. TDP-43 loss of function increases TFEB activity and blocks autophagosome-lysosome fusion. EMBO J. 2016, 35, 121-142. [CrossRef]

20. Araki, W.; Minegishi, S.; Motoki, K.; Kume, H.; Hohjoh, H.; Araki, Y.M.; Tamaoka, A. Disease-associated mutations of TDP-43 promote turnover of the protein through the proteasomal pathway. Mol. Neurobiol. 2014, 50, 1049-1058. [CrossRef]

21. Barmada, S.J.; Serio, A.; Arjun, A.; Bilican, B.; Daub, A.; Ando, D.M.; Tsvetkov, A.; Pleiss, M.; Li, X.; Peisach, D.; et al. Autophagy induction enhances TDP43 turnover and survival in neuronal ALS models. Nat. Chem. Biol. 2014, 10, 677-685. [CrossRef] [PubMed]

22. Liu, G.; Coyne, A.N.; Pei, F.; Vaughan, S.; Chaung, M.; Zarnescu, D.C.; Buchan, J.R. Endocytosis regulates TDP-43 toxicity and turnover. Nat. Commun. 2017, 8, 2092. [CrossRef] [PubMed]

23. Schwenk, B.M.; Hartmann, H.; Serdaroglu, A.; Schludi, M.H.; Hornburg, D.; Meissner, F.; Orozco, D.; Colombo, A.; Tahirovic, S.; Michaelsen, M.; et al. TDP-43 loss of function inhibits endosomal trafficking and alters trophic signaling in neurons. EMBO J. 2016, 35, 2350-2370. [CrossRef] [PubMed]

24. Dang, T.N.T.; Lim, N.K.H.; Grubman, A.; Li, Q.-X.; Volitakis, I.; White, A.R.; Crouch, P.J. Increased metal content in the TDP-43(A315T) transgenic mouse model of frontotemporal lobar degeneration and amyotrophic lateral sclerosis. Front. Aging Neurosci. 2014, 6, 15. [CrossRef] [PubMed]

25. Caragounis, A.; Price, K.A.; Soon, C.P.W.; Filiz, G.; Masters, C.L.; Li, Q.-X.; Crouch, P.J.; White, A.R. Zinc induces depletion and aggregation of endogenous TDP-43. Free Radic. Biol. Med. 2010, 48, 1152-1161. [CrossRef] [PubMed]

26. Berson, A.; Sartoris, A.; Nativio, R.; Van Deerlin, V.; Toledo, J.B.; Porta, S.; Liu, S.; Chung, C.-Y.; Garcia, B.A.; Lee, V.M.-Y.; et al. TDP-43 Promotes Neurodegeneration by Impairing Chromatin Remodeling. Curr. Biol. 2017, 27, 3579-3590.e6. [CrossRef] 
27. Sun, Z.; Diaz, Z.; Fang, X.; Hart, M.P.; Chesi, A.; Shorter, J.; Gitler, A.D. Molecular determinants and genetic modifiers of aggregation and toxicity for the ALS disease protein FUS/TLS. PLoS Biol. 2011, 9, e1000614. [CrossRef]

28. Marrone, L.; Drexler, H.C.A.; Wang, J.; Tripathi, P.; Distler, T.; Heisterkamp, P.; Anderson, E.N.; Kour, S.; Moraiti, A.; Maharana, S.; et al. FUS pathology in ALS is linked to alterations in multiple ALS-associated proteins and rescued by drugs stimulating autophagy. Acta Neuropathol. 2019, 138, 67-84. [CrossRef]

29. Lin, C.L.; Bristol, L.A.; Jin, L.; Dykes-Hoberg, M.; Crawford, T.; Clawson, L.; Rothstein, J.D. Aberrant RNA processing in a neurodegenerative disease: The cause for absent EAAT2, a glutamate transporter, in amyotrophic lateral sclerosis. Neuron 1998, 20, 589-602. [CrossRef]

30. Trotti, D.; Rolfs, A.; Danbolt, N.C.; Brown, R.H., Jr.; Hediger, M.A. SOD1 mutants linked to amyotrophic lateral sclerosis selectively inactivate a glial glutamate transporter. Nat. Neurosci. 1999, 2, 427-433. [CrossRef]

31. Chung, M.J.; Suh, Y.-L. Ultrastructural changes of mitochondria in the skeletal muscle of patients with amyotrophic lateral sclerosis. Ultrastruct. Pathol. 2002, 26, 3-7. [CrossRef] [PubMed]

32. Echaniz-Laguna, A.; Zoll, J.; Ribera, F.; Tranchant, C.; Warter, J.-M.; Lonsdorfer, J.; Lampert, E. Mitochondrial respiratory chain function in skeletal muscle of ALS patients. Ann. Neurol. 2002, 52, 623-627. [CrossRef] [PubMed]

33. Sasaki, S.; Iwata, M. Mitochondrial alterations in the spinal cord of patients with sporadic amyotrophic lateral sclerosis. J. Neuropathol. Exp. Neurol. 2007, 66, 10-16. [CrossRef] [PubMed]

34. Kieran, D.; Hafezparast, M.; Bohnert, S.; Dick, J.R.T.; Martin, J.; Schiavo, G.; Fisher, E.M.C.; Greensmith, L. A mutation in dynein rescues axonal transport defects and extends the life span of ALS mice. J. Cell Biol. 2005, 169, 561-567. [CrossRef] [PubMed]

35. Williamson, T.L.; Cleveland, D.W. Slowing of axonal transport is a very early event in the toxicity of ALS-linked SOD1 mutants to motor neurons. Nat. Neurosci. 1999, 2, 50-56. [CrossRef]

36. Bilsland, L.G.; Sahai, E.; Kelly, G.; Golding, M.; Greensmith, L.; Schiavo, G. Deficits in axonal transport precede ALS symptoms in vivo. Proc. Natl. Acad. Sci. USA 2010, 107, 20523-20528. [CrossRef] [PubMed]

37. Simpson, E.P.; Henry, Y.K.; Henkel, J.S.; Smith, R.G.; Appel, S.H. Increased lipid peroxidation in sera of ALS patients: A potential biomarker of disease burden. Neurology 2004, 62, 1758-1765. [CrossRef]

38. Chang, Y.; Kong, Q.; Shan, X.; Tian, G.; Ilieva, H.; Cleveland, D.W.; Rothstein, J.D.; Borchelt, D.R.; Wong, P.C.; Lin, C.-L.G. Messenger RNA oxidation occurs early in disease pathogenesis and promotes motor neuron degeneration in ALS. PLOS ONE 2008, 3, e2849. [CrossRef]

39. Becker, L.A.; Huang, B.; Bieri, G.; Ma, R.; Knowles, D.A.; Jafar-Nejad, P.; Messing, J.; Kim, H.J.; Soriano, A.; Auburger, G.; et al. Therapeutic reduction of ataxin-2 extends lifespan and reduces pathology in TDP-43 mice. Nature 2017, 544, 367-371. [CrossRef]

40. Elden, A.C.; Kim, H.-J.; Hart, M.P.; Chen-Plotkin, A.S.; Johnson, B.S.; Fang, X.; Armakola, M.; Geser, F.; Greene, R.; Lu, M.M.; et al. Ataxin-2 intermediate-length polyglutamine expansions are associated with increased risk for ALS. Nature 2010, 466, 1069-1075. [CrossRef]

41. Freischmidt, A.; Wieland, T.; Richter, B.; Ruf, W.; Schaeffer, V.; Müller, K.; Marroquin, N.; Nordin, F.; Hübers, A.; Weydt, P.; et al. Haploinsufficiency of TBK1 causes familial ALS and fronto-temporal dementia. Nat. Neurosci. 2015, 18, 631-636. [CrossRef] [PubMed]

42. Volles, M.J.; Lee, S.J.; Rochet, J.C.; Shtilerman, M.D.; Ding, T.T.; Kessler, J.C.; Lansbury, P.T., Jr. Vesicle permeabilization by protofibrillar alpha-synuclein: Implications for the pathogenesis and treatment of Parkinson's disease. Biochemistry 2001, 40, 7812-7819. [CrossRef] [PubMed]

43. Volles, M.J.; Lansbury, P.T., Jr. Vesicle permeabilization by protofibrillar alpha-synuclein is sensitive to Parkinson's disease-linked mutations and occurs by a pore-like mechanism. Biochemistry 2002, 41, 4595-4602. [CrossRef] [PubMed]

44. Zakharov, S.D.; Hulleman, J.D.; Dutseva, E.A.; Antonenko, Y.N.; Rochet, J.-C.; Cramer, W.A. Helical alpha-synuclein forms highly conductive ion channels. Biochemistry 2007, 46, 14369-14379. [CrossRef] [PubMed]

45. Pacheco, C.R.; Morales, C.N.; Ramírez, A.E.; Muñoz, F.J.; Gallegos, S.S.; Caviedes, P.A.; Aguayo, L.G.; Opazo, C.M. Extracellular $\alpha$-synuclein alters synaptic transmission in brain neurons by perforating the neuronal plasma membrane. J. Neurochem. 2015, 132, 731-741. [CrossRef] [PubMed]

46. Scott, D.A.; Tabarean, I.; Tang, Y.; Cartier, A.; Masliah, E.; Roy, S. A pathologic cascade leading to synaptic dysfunction in alpha-synuclein-induced neurodegeneration. J. Neurosci. 2010, 30, 8083-8095. [CrossRef]

47. Wersinger, C.; Vernier, P.; Sidhu, A. Trypsin disrupts the trafficking of the human dopamine transporter by alpha-synuclein and its A30P mutant. Biochemistry 2004, 43, 1242-1253. [CrossRef] 
48. Adamczyk, A.; Strosznajder, J.B. Alpha-synuclein potentiates $\mathrm{Ca}^{2+}$ influx through voltage-dependent $\mathrm{Ca}^{2+}$ channels. Neuroreport 2006, 17, 1883-1886. [CrossRef]

49. Danzer, K.M.; Haasen, D.; Karow, A.R.; Moussaud, S.; Habeck, M.; Giese, A.; Kretzschmar, H.; Hengerer, B.; Kostka, M. Different species of alpha-synuclein oligomers induce calcium influx and seeding. J. Neurosci. 2007, 27, 9220-9232. [CrossRef]

50. Alim, M.A.; Ma, Q.-L.; Takeda, K.; Aizawa, T.; Matsubara, M.; Nakamura, M.; Asada, A.; Saito, T.; Kaji, H.; Yoshii, M.; et al. Demonstration of a role for alpha-synuclein as a functional microtubule-associated protein. J. Alzheimers. Dis. 2004, 6, 435-442. [CrossRef]

51. Alim, M.A.; Hossain, M.S.; Arima, K.; Takeda, K.; Izumiyama, Y.; Nakamura, M.; Kaji, H.; Shinoda, T.; Hisanaga, S.; Ueda, K. Tubulin seeds alpha-synuclein fibril formation. J. Biol. Chem. 2002, 277, 2112-2117. [CrossRef] [PubMed]

52. Lee, H.-J.; Khoshaghideh, F.; Lee, S.; Lee, S.-J. Impairment of microtubule-dependent trafficking by overexpression of alpha-synuclein. Eur. J. Neurosci. 2006, 24, 3153-3162. [CrossRef] [PubMed]

53. McNaught, K.S.; Jenner, P. Proteasomal function is impaired in substantia nigra in Parkinson's disease. Neurosci. Lett. 2001, 297, 191-194. [CrossRef]

54. Lindersson, E.; Beedholm, R.; Højrup, P.; Moos, T.; Gai, W.; Hendil, K.B.; Jensen, P.H. Proteasomal inhibition by alpha-synuclein filaments and oligomers. J. Biol. Chem. 2004, 279, 12924-12934. [CrossRef]

55. Tanaka, Y.; Engelender, S.; Igarashi, S.; Rao, R.K.; Wanner, T.; Tanzi, R.E.; Sawa, A.; Dawson, V.L.; Dawson, T.M.; Ross, C.A. Inducible expression of mutant alpha-synuclein decreases proteasome activity and increases sensitivity to mitochondria-dependent apoptosis. Hum. Mol. Genet. 2001, 10, 919-926. [CrossRef]

56. Murphy, K.E.; Gysbers, A.M.; Abbott, S.K.; Tayebi, N.; Kim, W.S.; Sidransky, E.; Cooper, A.; Garner, B.; Halliday, G.M. Reduced glucocerebrosidase is associated with increased $\alpha$-synuclein in sporadic Parkinson's disease. Brain 2014, 137, 834-848. [CrossRef]

57. Papagiannakis, N.; Xilouri, M.; Koros, C.; Stamelou, M.; Antonelou, R.; Maniati, M.; Papadimitriou, D.; Moraitou, M.; Michelakakis, H.; Stefanis, L. Lysosomal alterations in peripheral blood mononuclear cells of Parkinson's disease patients. Mov. Disord. 2015, 30, 1830-1834. [CrossRef]

58. Hsu, L.J.; Sagara, Y.; Arroyo, A.; Rockenstein, E.; Sisk, A.; Mallory, M.; Wong, J.; Takenouchi, T.; Hashimoto, M.; Masliah, E. alpha-synuclein promotes mitochondrial deficit and oxidative stress. Am. J. Pathol. 2000, 157, 401-410. [CrossRef]

59. Devi, L.; Raghavendran, V.; Prabhu, B.M.; Avadhani, N.G.; Anandatheerthavarada, H.K. Mitochondrial import and accumulation of alpha-synuclein impair complex I in human dopaminergic neuronal cultures and Parkinson disease brain. J. Biol. Chem. 2008, 283, 9089-9100. [CrossRef]

60. Colla, E.; Coune, P.; Liu, Y.; Pletnikova, O.; Troncoso, J.C.; Iwatsubo, T.; Schneider, B.L.; Lee, M.K. Endoplasmic reticulum stress is important for the manifestations of $\alpha$-synucleinopathy in vivo. J. Neurosci. 2012, 32, 3306-3320. [CrossRef]

61. Gosavi, N.; Lee, H.-J.; Lee, J.S.; Patel, S.; Lee, S.-J. Golgi fragmentation occurs in the cells with prefibrillar alpha-synuclein aggregates and precedes the formation of fibrillar inclusion. J. Biol. Chem. 2002, 277, 48984-48992. [CrossRef] [PubMed]

62. Cooper, A.A.; Gitler, A.D.; Cashikar, A.; Haynes, C.M.; Hill, K.J.; Bhullar, B.; Liu, K.; Xu, K.; Strathearn, K.E.; Liu, F.; et al. Alpha-synuclein blocks ER-Golgi traffic and Rab1 rescues neuron loss in Parkinson's models. Science 2006, 313, 324-328. [CrossRef] [PubMed]

63. Jin, H.; Kanthasamy, A.; Ghosh, A.; Yang, Y.; Anantharam, V.; Kanthasamy, A.G. $\alpha$-Synuclein negatively regulates protein kinase $\mathrm{C} \delta$ expression to suppress apoptosis in dopaminergic neurons by reducing p300 histone acetyltransferase activity. J. Neurosci. 2011, 31, 2035-2051. [CrossRef] [PubMed]

64. Jin, H.; Kanthasamy, A.; Harischandra, D.S.; Kondru, N.; Ghosh, A.; Panicker, N.; Anantharam, V.; Rana, A.; Kanthasamy, A.G. Histone hyperacetylation up-regulates protein kinase $\mathrm{C} \delta$ in dopaminergic neurons to induce cell death: Relevance to epigenetic mechanisms of neurodegeneration in Parkinson disease. J. Biol. Chem. 2014, 289, 34743-34767. [CrossRef]

65. Kontopoulos, E.; Parvin, J.D.; Feany, M.B. Alpha-synuclein acts in the nucleus to inhibit histone acetylation and promote neurotoxicity. Hum. Mol. Genet. 2006, 15, 3012-3023. [CrossRef]

66. Xu, X.; Zhuang, C.; Wu, Z.; Qiu, H.; Feng, H.; Wu, J. LincRNA-p21 Inhibits Cell Viability and Promotes Cell Apoptosis in Parkinson's Disease through Activating $\alpha$-Synuclein Expression. Biomed. Res. Int. 2018, 2018, 8181374. [CrossRef] 
67. Desplats, P.; Lee, H.-J.; Bae, E.-J.; Patrick, C.; Rockenstein, E.; Crews, L.; Spencer, B.; Masliah, E.; Lee, S.-J. Inclusion formation and neuronal cell death through neuron-to-neuron transmission of alpha-synuclein. Proc. Natl. Acad. Sci. USA 2009, 106, 13010-13015. [CrossRef]

68. Canale, C.; Seghezza, S.; Vilasi, S.; Carrotta, R.; Bulone, D.; Diaspro, A.; San Biagio, P.L.; Dante, S. Different effects of Alzheimer's peptide A $\beta(1-40)$ oligomers and fibrils on supported lipid membranes. Biophys. Chem. 2013, 182, 23-29. [CrossRef]

69. Bode, D.C.; Freeley, M.; Nield, J.; Palma, M.; Viles, J.H. Amyloid- $\beta$ oligomers have a profound detergent-like effect on lipid membrane bilayers, imaged by atomic force and electron microscopy. J. Biol. Chem. 2019, 294, 7566-7572. [CrossRef]

70. Hoover, B.R.; Reed, M.N.; Su, J.; Penrod, R.D.; Kotilinek, L.A.; Grant, M.K.; Pitstick, R.; Carlson, G.A.; Lanier, L.M.; Yuan, L.-L.; et al. Tau mislocalization to dendritic spines mediates synaptic dysfunction independently of neurodegeneration. Neuron 2010, 68, 1067-1081. [CrossRef]

71. Teravskis, P.J.; Oxnard, B.R.; Miller, E.C.; Kemper, L.; Ashe, K.H.; Liao, D. Phosphorylation in two discrete tau domains regulates a stepwise process leading to postsynaptic dysfunction. J. Physiol. 2019. [CrossRef] [PubMed]

72. Ding, Y.; Zhao, J.; Zhang, X.; Wang, S.; Viola, K.L.; Chow, F.E.; Zhang, Y.; Lippa, C.; Klein, W.L.; Gong, Y. Amyloid Beta Oligomers Target to Extracellular and Intracellular Neuronal Synaptic Proteins in Alzheimer's Disease. Front. Neurol. 2019, 10, 1140. [CrossRef] [PubMed]

73. Abd-Elrahman, K.S.; Hamilton, A.; Albaker, A.; Ferguson, S.S.G. mGluR5 Contribution to Neuropathology in Alzheimer Mice Is Disease Stage-Dependent. ACS Pharmacol. Transl. Sci. 2020, 3, 334-344. [CrossRef] [PubMed]

74. Greotti, E.; Capitanio, P.; Wong, A.; Pozzan, T.; Pizzo, P.; Pendin, D. Familial Alzheimer's disease-linked presenilin mutants and intracellular Ca handling: A single-organelle, FRET-based analysis. Cell Calcium 2019, 79, 44-56. [CrossRef] [PubMed]

75. Balducci, C.; Beeg, M.; Stravalaci, M.; Bastone, A.; Sclip, A.; Biasini, E.; Tapella, L.; Colombo, L.; Manzoni, C.; Borsello, T.; et al. Synthetic amyloid-beta oligomers impair long-term memory independently of cellular prion protein. Proc. Natl. Acad. Sci. USA 2010, 107, 2295-2300. [CrossRef] [PubMed]

76. Androuin, A.; Potier, B.; Nägerl, U.V.; Cattaert, D.; Danglot, L.; Thierry, M.; Youssef, I.; Triller, A.; Duyckaerts, C.; El Hachimi, K.H.; et al. Evidence for altered dendritic spine compartmentalization in Alzheimer's disease and functional effects in a mouse model. Acta Neuropathol. 2018, 135, 839-854. [CrossRef] [PubMed]

77. Youssef, P.; Chami, B.; Lim, J.; Middleton, T.; Sutherland, G.T.; Witting, P.K. Evidence supporting oxidative stress in a moderately affected area of the brain in Alzheimer's disease. Sci. Rep. 2018, 8, 11553. [CrossRef]

78. Majd, S.; Power, J.H.T. Oxidative Stress and Decreased Mitochondrial Superoxide Dismutase 2 and Peroxiredoxins 1 and 4 Based Mechanism of Concurrent Activation of AMPK and mTOR in Alzheimer's Disease. Curr. Alzheimer Res. 2018, 15, 764-776. [CrossRef]

79. Wang, J.; Zhao, C.; Zhao, A.; Li, M.; Ren, J.; Qu, X. New insights in amyloid beta interactions with human telomerase. J. Am. Chem. Soc. 2015, 137, 1213-1219. [CrossRef]

80. Zhang, J.; Kong, Q.; Zhang, Z.; Ge, P.; Ba, D.; He, W. Telomere dysfunction of lymphocytes in patients with Alzheimer disease. Cogn. Behav. Neurol. 2003, 16, 170-176. [CrossRef]

81. Adav, S.S.; Park, J.E.; Sze, S.K. Quantitative profiling brain proteomes revealed mitochondrial dysfunction in Alzheimer's disease. Mol. Brain 2019, 12, 8. [CrossRef] [PubMed]

82. Reddy, P.H.; Yin, X.; Manczak, M.; Kumar, S.; Pradeepkiran, J.A.; Vijayan, M.; Reddy, A.P. Mutant APP and amyloid beta-induced defective autophagy, mitophagy, mitochondrial structural and functional changes and synaptic damage in hippocampal neurons from Alzheimer's disease. Hum. Mol. Genet. 2018, 27, 2502-2516. [CrossRef] [PubMed]

83. Peña-Bautista, C.; López-Cuevas, R.; Cuevas, A.; Baquero, M.; Cháfer-Pericás, C. Lipid peroxidation biomarkers correlation with medial temporal atrophy in early Alzheimer Disease. Neurochem. Int. 2019, 129, 104519. [CrossRef] [PubMed]

84. Sondag, C.M.; Dhawan, G.; Combs, C.K. Beta amyloid oligomers and fibrils stimulate differential activation of primary microglia. J. Neuroinflammation 2009, 6, 1. [CrossRef] [PubMed]

85. Pan, X.-D.; Zhu, Y.-G.; Lin, N.; Zhang, J.; Ye, Q.-Y.; Huang, H.-P.; Chen, X.-C. Microglial phagocytosis induced by fibrillar $\beta$-amyloid is attenuated by oligomeric $\beta$-amyloid: Implications for Alzheimer's disease. Mol. Neurodegener. 2011, 6, 45. [CrossRef] [PubMed] 
86. Combs, C.K.; Karlo, J.C.; Kao, S.C.; Landreth, G.E. beta-Amyloid stimulation of microglia and monocytes results in TNFalpha-dependent expression of inducible nitric oxide synthase and neuronal apoptosis. J. Neurosci. 2001, 21, 1179-1188. [CrossRef]

87. Finkbeiner, S. Huntington's Disease. Cold Spring Harb. Perspect. Biol. 2011, 3, a007476. [CrossRef]

88. Arndt, J.R.; Chaibva, M.; Legleiter, J. The emerging role of the first 17 amino acids of huntingtin in Huntington's disease. Biomol. Concepts 2015, 6, 33-46. [CrossRef]

89. Jimenez-Sanchez, M.; Licitra, F.; Underwood, B.R.; Rubinsztein, D.C. Huntington's Disease: Mechanisms of Pathogenesis and Therapeutic Strategies. Cold Spring Harb. Perspect. Med. 2017, 7, a024240. [CrossRef]

90. Kremer, B.; Goldberg, P.; Andrew, S.E.; Theilmann, J.; Telenius, H.; Zeisler, J.; Squitieri, F.; Lin, B.; Bassett, A.; Almqvist, E. A worldwide study of the Huntington's disease mutation. The sensitivity and specificity of measuring CAG repeats. N. Engl. J. Med. 1994, 330, 1401-1406. [CrossRef]

91. Zala, D.; Hinckelmann, M.-V.; Saudou, F. Huntingtin's function in axonal transport is conserved in Drosophila melanogaster. PLoS ONE 2013, 8, e60162. [CrossRef] [PubMed]

92. Caviston, J.P.; Ross, J.L.; Antony, S.M.; Tokito, M.; Holzbaur, E.L.F. Huntingtin facilitates dynein/dynactin-mediated vesicle transport. Proc. Natl. Acad. Sci. USA 2007, 104, 10045-10050. [CrossRef] [PubMed]

93. Liot, G.; Zala, D.; Pla, P.; Mottet, G.; Piel, M.; Saudou, F. Mutant Huntingtin alters retrograde transport of TrkB receptors in striatal dendrites. J. Neurosci. 2013, 33, 6298-6309. [CrossRef] [PubMed]

94. Wong, Y.C.; Holzbaur, E.L.F. The regulation of autophagosome dynamics by huntingtin and HAP1 is disrupted by expression of mutant huntingtin, leading to defective cargo degradation. J. Neurosci. 2014, 34, 1293-1305. [CrossRef] [PubMed]

95. Wu, L.L.-Y.; Fan, Y.; Li, S.; Li, X.-J.; Zhou, X.-F. Huntingtin-associated protein-1 interacts with pro-brain-derived neurotrophic factor and mediates its transport and release. J. Biol. Chem. 2010, 285, 5614-5623. [CrossRef] [PubMed]

96. Twelvetrees, A.E.; Yuen, E.Y.; Arancibia-Carcamo, I.L.; MacAskill, A.F.; Rostaing, P.; Lumb, M.J.; Humbert, S.; Triller, A.; Saudou, F.; Yan, Z.; et al. Delivery of GABAARs to synapses is mediated by HAP1-KIF5 and disrupted by mutant huntingtin. Neuron 2010, 65, 53-65. [CrossRef]

97. Elias, S.; Thion, M.S.; Yu, H.; Sousa, C.M.; Lasgi, C.; Morin, X.; Humbert, S. Huntingtin regulates mammary stem cell division and differentiation. Stem Cell Reports 2014, 2, 491-506. [CrossRef]

98. Reiner, A.; Dragatsis, I.; Zeitlin, S.; Goldowitz, D. Wild-type huntingtin plays a role in brain development and neuronal survival. Mol. Neurobiol. 2003, 28, 259-276. [CrossRef]

99. Adegbuyiro, A.; Sedighi, F.; Pilkington, A.W., 4th; Groover, S.; Legleiter, J. Proteins Containing Expanded Polyglutamine Tracts and Neurodegenerative Disease. Biochemistry 2017, 56, 1199-1217.

100. Ross, C.A.; Tabrizi, S.J. Huntington's disease: From molecular pathogenesis to clinical treatment. Lancet Neurol. 2011, 10, 83-98. [CrossRef]

101. Ambrose, C.M.; Duyao, M.P.; Barnes, G.; Bates, G.P.; Lin, C.S.; Srinidhi, J.; Baxendale, S.; Hummerich, H.; Lehrach, H.; Altherr, M.; et al. Structure and expression of the Huntington's disease gene: Evidence against simple inactivation due to an expanded CAG repeat. Somat. Cell Mol. Genet. 1994, 20, 27-38. [CrossRef] [PubMed]

102. Nasir, J.; Floresco, S.B.; O’Kusky, J.R.; Diewert, V.M.; Richman, J.M.; Zeisler, J.; Borowski, A.; Marth, J.D.; Phillips, A.G.; Hayden, M.R. Targeted disruption of the Huntington's disease gene results in embryonic lethality and behavioral and morphological changes in heterozygotes. Cell 1995, 81, 811-823. [CrossRef]

103. Zhang, S.; Feany, M.B.; Saraswati, S.; Littleton, J.T.; Perrimon, N. Inactivation of Drosophila Huntingtin affects long-term adult functioning and the pathogenesis of a Huntington's disease model. Dis. Model. Mech. 2009, 2, 247-266. [CrossRef] [PubMed]

104. Zeitler, B.; Froelich, S.; Marlen, K.; Shivak, D.A.; Yu, Q.; Li, D.; Pearl, J.R.; Miller, J.C.; Zhang, L.; Paschon, D.E.; et al. Allele-selective transcriptional repression of mutant HTT for the treatment of Huntington's disease. Nat. Med. 2019, 25, 1131-1142. [CrossRef] [PubMed]

105. Tabrizi, S.J.; Leavitt, B.R.; Landwehrmeyer, G.B.; Wild, E.J.; Saft, C.; Barker, R.A.; Blair, N.F.; Craufurd, D.; Priller, J.; Rickards, H.; et al. Targeting Huntingtin Expression in Patients with Huntington's Disease. N. Engl. J. Med. 2019, 380, 2307-2316. [CrossRef]

106. Kiernan, M.C.; Vucic, S.; Cheah, B.C.; Turner, M.R.; Eisen, A.; Hardiman, O.; Burrell, J.R.; Zoing, M.C. Amyotrophic lateral sclerosis. Lancet 2011, 377, 942-955. [CrossRef] 
107. Prasad, A.; Bharathi, V.; Sivalingam, V.; Girdhar, A.; Patel, B.K. Molecular Mechanisms of TDP-43 Misfolding and Pathology in Amyotrophic Lateral Sclerosis. Front. Mol. Neurosci. 2019, 12, 25. [CrossRef]

108. Geuens, T.; Bouhy, D.; Timmerman, V. The hnRNP family: Insights into their role in health and disease. Hum. Genet. 2016, 135, 851-867. [CrossRef]

109. Afroz, T.; Hock, E.-M.; Ernst, P.; Foglieni, C.; Jambeau, M.; Gilhespy, L.A.B.; Laferriere, F.; Maniecka, Z.; Plückthun, A.; Mittl, P.; et al. Functional and dynamic polymerization of the ALS-linked protein TDP-43 antagonizes its pathologic aggregation. Nat. Commun. 2017, 8, 45. [CrossRef]

110. Afroz, T.; Pérez-Berlanga, M.; Polymenidou, M. Structural Transition, Function and Dysfunction of TDP-43 in Neurodegenerative Diseases. Chimia 2019, 73, 380-390. [CrossRef]

111. Baskaran, P.; Shaw, C.; Guthrie, S. TDP-43 causes neurotoxicity and cytoskeletal dysfunction in primary cortical neurons. PLoS ONE 2018, 13, e0196528. [CrossRef] [PubMed]

112. Hergesheimer, R.C.; Chami, A.A.; De Assis, D.R.; Vourc'h, P.; Andres, C.R.; Corcia, P.; Lanznaster, D.; Blasco, H. The debated toxic role of aggregated TDP-43 in amyotrophic lateral sclerosis: A resolution in sight? Brain 2019, 142, 1176-1194. [CrossRef] [PubMed]

113. Sun, Y.; Chakrabartty, A. Phase to Phase with TDP-43. Biochemistry 2017, 56, 809-823. [PubMed]

114. Ishigaki, S.; Sobue, G. Importance of Functional Loss of FUS in FTLD/ALS. Front. Mol. Biosci. $2018,5,44$. [CrossRef] [PubMed]

115. Lindström, M.; Liu, B. Yeast as a Model to Unravel Mechanisms Behind FUS Toxicity in Amyotrophic Lateral Sclerosis. Front. Mol. Neurosci. 2018, 11, 218. [CrossRef]

116. Kaur, S.J.; McKeown, S.R.; Rashid, S. Mutant SOD1 mediated pathogenesis of Amyotrophic Lateral Sclerosis. Gene 2016, 577, 109-118. [CrossRef] [PubMed]

117. Zarei, S.; Carr, K.; Reiley, L.; Diaz, K.; Guerra, O.; Altamirano, P.F.; Pagani, W.; Lodin, D.; Orozco, G.; Chinea, A. A comprehensive review of amyotrophic lateral sclerosis. Surg. Neurol. Int. 2015, 6, 171. [CrossRef]

118. Silverman, J.M.; Fernando, S.M.; Grad, L.I.; Hill, A.F.; Turner, B.J.; Yerbury, J.J.; Cashman, N.R. Disease Mechanisms in ALS: Misfolded SOD1 Transferred Through Exosome-Dependent and Exosome-Independent Pathways. Cell. Mol. Neurobiol. 2016, 36, 377-381. [CrossRef]

119. Oakes, J.A.; Davies, M.C.; Collins, M.O. TBK1: A new player in ALS linking autophagy and neuroinflammation. Mol. Brain 2017, 10, 5. [CrossRef]

120. Prasad, A.; Raju, G.; Sivalingam, V.; Girdhar, A.; Verma, M.; Vats, A.; Taneja, V.; Prabusankar, G.; Patel, B.K. An acridine derivative, [4,5-bis $\{(\mathrm{N}$-carboxy methyl imidazolium)methyl $\}$ acridine] dibromide, shows anti-TDP-43 aggregation effect in ALS disease models. Sci. Rep. 2016, 6, 39490. [CrossRef]

121. Cassel, J.A.; McDonnell, M.E.; Velvadapu, V.; Andrianov, V.; Reitz, A.B. Characterization of a series of 4-aminoquinolines that stimulate caspase-7 mediated cleavage of TDP-43 and inhibit its function. Biochimie 2012, 94, 1974-1981. [CrossRef] [PubMed]

122. Jackrel, M.E.; DeSantis, M.E.; Martinez, B.A.; Castellano, L.M.; Stewart, R.M.; Caldwell, K.A.; Caldwell, G.A.; Shorter, J. Potentiated Hsp104 variants antagonize diverse proteotoxic misfolding events. Cell 2014, 156, 170-182. [CrossRef] [PubMed]

123. Yoshizawa, T.; Ali, R.; Jiou, J.; Fung, H.Y.J.; Burke, K.A.; Kim, S.J.; Lin, Y.; Peeples, W.B.; Saltzberg, D.; Soniat, M.; et al. Nuclear Import Receptor Inhibits Phase Separation of FUS through Binding to Multiple Sites. Cell 2018, 173, 693-705.e22. [CrossRef] [PubMed]

124. Weiss, M.D.; Macklin, E.A.; Simmons, Z.; Knox, A.S.; Greenblatt, D.J.; Atassi, N.; Graves, M.; Parziale, N.; Salameh, J.S.; Quinn, C.; et al. A randomized trial of mexiletine in ALS: Safety and effects on muscle cramps and progression. Neurology 2016, 86, 1474-1481. [CrossRef] [PubMed]

125. Takei, K.; Watanabe, K.; Yuki, S.; Akimoto, M.; Sakata, T.; Palumbo, J. Edaravone and its clinical development for amyotrophic lateral sclerosis. Amyotroph. Lateral Scler. Frontotemporal. Degener. 2017, 18, 5-10. [CrossRef] [PubMed]

126. Mandrioli, J.; D’Amico, R.; Zucchi, E.; Gessani, A.; Fini, N.; Fasano, A.; Caponnetto, C.; Chiò, A.; Dalla Bella, E.; Lunetta, C.; et al. Rapamycin treatment for amyotrophic lateral sclerosis: Protocol for a phase II randomized, double-blind, placebo-controlled, multicenter, clinical trial (RAP-ALS trial). Medicine 2018, 97, e11119. [CrossRef]

127. Takahashi, S.; Morimoto, S.; Okano, H. Ropinirole Hydrochloride, a Candidate Drug for ALS Treatment. Brain Nerve 2019, 71, 943-952.

128. Chen, P.-C.; Hsieh, Y.-C.; Huang, C.-C.; Hu, C.-J. Tamoxifen for amyotrophic lateral sclerosis: A randomized double-blind clinical trial. Medicine 2020, 99, e20423. [CrossRef] 
129. Benatar, M.; Wuu, J.; Andersen, P.M.; Atassi, N.; David, W.; Cudkowicz, M.; Schoenfeld, D. Randomized, double-blind, placebo-controlled trial of arimoclomol in rapidly progressive ALS. Neurology 2018, 90, e565-e574. [CrossRef]

130. Polymeropoulos, M.H.; Lavedan, C.; Leroy, E.; Ide, S.E.; Dehejia, A.; Dutra, A.; Pike, B.; Root, H.; Rubenstein, J.; Boyer, R.; et al. Mutation in the alpha-synuclein gene identified in families with Parkinson's disease. Science 1997, 276, 2045-2047. [CrossRef]

131. Spillantini, M.G.; Crowther, R.A.; Jakes, R.; Hasegawa, M.; Goedert, M. Alpha-Synuclein in filamentous inclusions of Lewy bodies from Parkinson's disease and dementia with lewy bodies. Proc. Natl. Acad. Sci. USA 1998, 95, 6469-6473. [CrossRef] [PubMed]

132. Spillantini, M.G.; Schmidt, M.L.; Lee, V.M.; Trojanowski, J.Q.; Jakes, R.; Goedert, M. Alpha-synuclein in Lewy bodies. Nature 1997, 388, 839-840. [CrossRef] [PubMed]

133. Klingelhoefer, L.; Reichmann, H. Parkinson's disease as a multisystem disorder. J. Neural. Transm. 2017, 124, 709-713. [CrossRef] [PubMed]

134. Angot, E.; Brundin, P. Dissecting the potential molecular mechanisms underlying alpha-synuclein cell-to-cell transfer in Parkinson's disease. Parkinsonism Relat. Disord. 2009, 15, S143-S147. [CrossRef]

135. Burré, J.; Sharma, M.; Tsetsenis, T.; Buchman, V.; Etherton, M.R.; Südhof, T.C. Alpha-synuclein promotes SNARE-complex assembly in vivo and in vitro. Science 2010, 329, 1663-1667. [CrossRef]

136. Surguchov, A. Molecular and cellular biology of synucleins. Int. Rev. Cell Mol. Biol. 2008, 270, $225-317$.

137. Cheng, F.; Vivacqua, G.; Yu, S. The role of $\alpha$-synuclein in neurotransmission and synaptic plasticity. J. Chem. Neuroanat. 2011, 42, 242-248. [CrossRef]

138. Benskey, M.J.; Perez, R.G.; Manfredsson, F.P. The contribution of alpha synuclein to neuronal survival and function-Implications for Parkinson's disease. J. Neurochem. 2016, 137, 331-359. [CrossRef]

139. Uéda, K.; Fukushima, H.; Masliah, E.; Xia, Y.; Iwai, A.; Yoshimoto, M.; Otero, D.A.; Kondo, J.; Ihara, Y.; Saitoh, T. Molecular cloning of cDNA encoding an unrecognized component of amyloid in Alzheimer disease. Proc. Natl. Acad. Sci. USA 1993, 90, 11282-11286. [CrossRef]

140. Park, S.M.; Jung, H.Y.; Chung, K.C.; Rhim, H.; Park, J.H.; Kim, J. Stress-induced aggregation profiles of GST-alpha-synuclein fusion proteins: Role of the C-terminal acidic tail of alpha-synuclein in protein thermosolubility and stability. Biochemistry 2002, 41, 4137-4146. [CrossRef]

141. Park, S.M.; Ahn, K.J.; Jung, H.Y.; Park, J.H.; Kim, J. Effects of novel peptides derived from the acidic tail of synuclein (ATS) on the aggregation and stability of fusion proteins. Protein Eng. Des. Sel. 2004, 17, 251-260. [CrossRef] [PubMed]

142. Bartels, T.; Choi, J.G.; Selkoe, D.J. $\alpha$-Synuclein occurs physiologically as a helically folded tetramer that resists aggregation. Nature 2011, 477, 107-110. [CrossRef] [PubMed]

143. Binolfi, A.; Theillet, F.-X.; Selenko, P. Bacterial in-cell NMR of human $\alpha$-synuclein: A disordered monomer by nature? Biochem. Soc. Trans. 2012, 40, 950-954. [CrossRef] [PubMed]

144. Fauvet, B.; Mbefo, M.K.; Fares, M.-B.; Desobry, C.; Michael, S.; Ardah, M.T.; Tsika, E.; Coune, P.; Prudent, M.; Lion, N.; et al. $\alpha$-Synuclein in central nervous system and from erythrocytes, mammalian cells, and Escherichia coli exists predominantly as disordered monomer. J. Biol. Chem. 2012, 287, 15345-15364. [CrossRef] [PubMed]

145. Wood, S.J.; Wypych, J.; Steavenson, S.; Louis, J.C.; Citron, M.; Biere, A.L. Alpha-synuclein fibrillogenesis is nucleation-dependent. Implications for the pathogenesis of Parkinson's disease. J. Biol. Chem. 1999, 274, 19509-19512. [CrossRef]

146. Lee, C.-C.; Nayak, A.; Sethuraman, A.; Belfort, G.; McRae, G.J. A three-stage kinetic model of amyloid fibrillation. Biophys. J. 2007, 92, 3448-3458. [CrossRef]

147. Eisele, Y.S.; Monteiro, C.; Fearns, C.; Encalada, S.E.; Wiseman, R.L.; Powers, E.T.; Kelly, J.W. Targeting protein aggregation for the treatment of degenerative diseases. Nat. Rev. Drug Discov. 2015, 14, 759-780. [CrossRef]

148. Narhi, L.; Wood, S.J.; Steavenson, S.; Jiang, Y.; Wu, G.M.; Anafi, D.; Kaufman, S.A.; Martin, F.; Sitney, K.; Denis, P.; et al. Both familial Parkinson's disease mutations accelerate alpha-synuclein aggregation. J. Biol. Chem. 1999, 274, 9843-9846. [CrossRef]

149. Conway, K.A.; Lee, S.J.; Rochet, J.C.; Ding, T.T.; Williamson, R.E.; Lansbury, P.T., Jr. Acceleration of oligomerization, not fibrillization, is a shared property of both alpha-synuclein mutations linked to early-onset Parkinson's disease: Implications for pathogenesis and therapy. Proc. Natl. Acad. Sci. USA 2000, 97, 571-576. [CrossRef] 
150. Breydo, L.; Wu, J.W.; Uversky, V.N. A-synuclein misfolding and Parkinson's disease. Biochim. Biophys. Acta 2012, 1822, 261-285. [CrossRef]

151. Goers, J.; Manning-Bog, A.B.; McCormack, A.L.; Millett, I.S.; Doniach, S.; Di Monte, D.A.; Uversky, V.N.; Fink, A.L. Nuclear localization of alpha-synuclein and its interaction with histones. Biochemistry 2003, 42, 8465-8471. [CrossRef] [PubMed]

152. Van Rooijen, B.D.; Claessens, M.M.A.E.; Subramaniam, V. Membrane Permeabilization by Oligomeric -Synuclein: In Search of the Mechanism. PLoS ONE 2010, 5, e14292. [CrossRef] [PubMed]

153. Tosatto, L.; Andrighetti, A.O.; Plotegher, N.; Antonini, V.; Tessari, I.; Ricci, L.; Bubacco, L.; Dalla Serra, M. Alpha-synuclein pore forming activity upon membrane association. Biochim. Biophys. Acta 2012, 1818, 2876-2883. [CrossRef] [PubMed]

154. Tsigelny, I.F.; Sharikov, Y.; Wrasidlo, W.; Gonzalez, T.; Desplats, P.A.; Crews, L.; Spencer, B.; Masliah, E. Role of $\alpha$-synuclein penetration into the membrane in the mechanisms of oligomer pore formation. FEBS J. 2012, 279, 1000-1013. [CrossRef]

155. Lashuel, H.A.; Overk, C.R.; Oueslati, A.; Masliah, E. The many faces of $\alpha$-synuclein: From structure and toxicity to therapeutic target. Nat. Rev. Neurosci. 2013, 14, 38-48. [CrossRef]

156. Gan-Or, Z.; Dion, P.A.; Rouleau, G.A. Genetic perspective on the role of the autophagy-lysosome pathway in Parkinson disease. Autophagy 2015, 11, 1443-1457. [CrossRef]

157. Chu, Y.; Dodiya, H.; Aebischer, P.; Olanow, C.W.; Kordower, J.H. Alterations in lysosomal and proteasomal markers in Parkinson's disease: Relationship to alpha-synuclein inclusions. Neurobiol. Dis. 2009, 35, 385-398. [CrossRef]

158. Liu, G.; Zhang, C.; Yin, J.; Li, X.; Cheng, F.; Li, Y.; Yang, H.; Uéda, K.; Chan, P.; Yu, S. $\alpha$-Synuclein is differentially expressed in mitochondria from different rat brain regions and dose-dependently down-regulates complex I activity. Neurosci. Lett. 2009, 454, 187-192. [CrossRef]

159. Mullin, S.; Smith, L.; Lee, K.; D’Souza, G.; Woodgate, P.; Elflein, J.; Hällqvist, J.; Toffoli, M.; Streeter, A.; Hosking, J.; et al. Ambroxol for the Treatment of Patients With Parkinson Disease With and Without Glucocerebrosidase Gene Mutations: A Nonrandomized, Noncontrolled Trial. JAMA Neurol. 2020, 77, 427-434. [CrossRef]

160. McFarthing, K.; Simuni, T. Clinical Trial Highlights: Targetting $\alpha$-Synuclein. J. Parkinsons. Dis. 2019, 9, 5-16. [CrossRef]

161. Schenk, D.B.; Koller, M.; Ness, D.K.; Griffith, S.G.; Grundman, M.; Zago, W.; Soto, J.; Atiee, G.; Ostrowitzki, S.; Kinney, G.G. First-in-human assessment of PRX002, an anti- $\alpha$-synuclein monoclonal antibody, in healthy volunteers. Mov. Disord. 2017, 32, 211-218. [CrossRef] [PubMed]

162. Jankovic, J.; Goodman, I.; Safirstein, B.; Marmon, T.K.; Schenk, D.B.; Koller, M.; Zago, W.; Ness, D.K.; Griffith, S.G.; Grundman, M.; et al. Safety and Tolerability of Multiple Ascending Doses of PRX002/RG7935, an Anti- $\alpha$-Synuclein Monoclonal Antibody, in Patients With Parkinson Disease: A Randomized Clinical Trial. JAMA Neurol. 2018, 75, 1206-1214. [CrossRef] [PubMed]

163. Brys, M.; Fanning, L.; Hung, S.; Ellenbogen, A.; Penner, N.; Yang, M.; Welch, M.; Koenig, E.; David, E.; Fox, T.; et al. Randomized phase I clinical trial of anti- $\alpha$-synuclein antibody BIIB054. Mov. Disord. 2019, 34, 1154-1163. [CrossRef] [PubMed]

164. Crous-Bou, M.; Minguillón, C.; Gramunt, N.; Molinuevo, J.L. Alzheimer's disease prevention: From risk factors to early intervention. Alzheimers. Res. Ther. 2017, 9, 71. [CrossRef] [PubMed]

165. 2020 Alzheimer's disease facts and figures. Alzheimers. Dement. 2020. [CrossRef]

166. Di Resta, C.; Ferrari, M. New molecular approaches to Alzheimer's disease. Clin. Biochem. 2019, 72, 81-86. [CrossRef]

167. Long, J.M.; Holtzman, D.M. Alzheimer Disease: An Update on Pathobiology and Treatment Strategies. Cell 2019, 179, 312-339. [CrossRef]

168. Hampel, H.; Vassar, R.; De Strooper, B.; Hardy, J.; Willem, M.; Singh, N.; Zhou, J.; Yan, R.; Vanmechelen, E.; De Vos, A.; et al. The $\beta$-Secretase BACE1 in Alzheimer's Disease. Biol. Psychiatry 2020. [CrossRef]

169. Colvin, M.T.; Silvers, R.; Ni, Q.Z.; Can, T.V.; Sergeyev, I.; Rosay, M.; Donovan, K.J.; Michael, B.; Wall, J.; Linse, S.; et al. Atomic Resolution Structure of Monomorphic A $\beta 42$ Amyloid Fibrils. J. Am. Chem. Soc. 2016, 138, 9663-9674. [CrossRef]

170. Riek, R.; Eisenberg, D.S. The activities of amyloids from a structural perspective. Nature 2016, 539, 227-235. [CrossRef] 
171. Yamamoto, N.; Tsuhara, S.; Tamura, A.; Chatani, E. A specific form of prefibrillar aggregates that functions as a precursor of amyloid nucleation. Sci. Rep. 2018, 8, 62. [CrossRef] [PubMed]

172. Morris, C.; Cupples, S.; Kent, T.W.; Elbassal, E.A.; Wojcikiewicz, E.P.; Yi, P.; Du, D. N-Terminal Charged Residues of Amyloid- $\beta$ Peptide Modulate Amyloidogenesis and Interaction with Lipid Membrane. Chemistry 2018, 24, 9494-9498. [CrossRef] [PubMed]

173. Sciacca, M.F.M.; Kotler, S.A.; Brender, J.R.; Chen, J.; Lee, D.-K.; Ramamoorthy, A. Two-step mechanism of membrane disruption by $A \beta$ through membrane fragmentation and pore formation. Biophys. J. 2012, 103, 702-710. [CrossRef] [PubMed]

174. Groemer, T.W.; Thiel, C.S.; Holt, M.; Riedel, D.; Hua, Y.; Hüve, J.; Wilhelm, B.G.; Klingauf, J. Amyloid precursor protein is trafficked and secreted via synaptic vesicles. PLoS ONE 2011, 6, e18754. [CrossRef] [PubMed]

175. Jiang, S.; Li, Y.; Zhang, X.; Bu, G.; Xu, H.; Zhang, Y.-W. Trafficking regulation of proteins in Alzheimer's disease. Mol. Neurodegener. 2014, 9, 6. [CrossRef]

176. Müller, U.C.; Deller, T.; Korte, M. Not just amyloid: Physiological functions of the amyloid precursor protein family. Nat. Rev. Neurosci. 2017, 18, 281-298. [CrossRef]

177. Deyts, C.; Thinakaran, G.; Parent, A.T. APP Receptor? To Be or Not To Be. Trends Pharmacol. Sci. 2016, 37, 390-411. [CrossRef]

178. Morrissey, J.A.; Mockett, B.G.; Singh, A.; Kweon, D.; Ohline, S.M.; Tate, W.P.; Hughes, S.M.; Abraham, W.C. A C-terminal peptide from secreted amyloid precursor protein- $\alpha$ enhances long-term potentiation in rats and a transgenic mouse model of Alzheimer's disease. Neuropharmacology 2019, 157, 107670. [CrossRef]

179. Rice, H.C.; De Malmazet, D.; Schreurs, A.; Frere, S.; Van Molle, I.; Volkov, A.N.; Creemers, E.; Vertkin, I.; Nys, J.; Ranaivoson, F.M.; et al. Secreted amyloid- $\beta$ precursor protein functions as a GABAR1a ligand to modulate synaptic transmission. Science 2019, 363, eaao4827. [CrossRef]

180. Gulisano, W.; Melone, M.; Li Puma, D.D.; Tropea, M.R.; Palmeri, A.; Arancio, O.; Grassi, C.; Conti, F.; Puzzo, D. The effect of amyloid- $\beta$ peptide on synaptic plasticity and memory is influenced by different isoforms, concentrations, and aggregation status. Neurobiol. Aging 2018, 71, 51-60. [CrossRef]

181. Gulisano, W.; Melone, M.; Ripoli, C.; Tropea, M.R.; Li Puma, D.D.; Giunta, S.; Cocco, S.; Marcotulli, D.; Origlia, N.; Palmeri, A.; et al. Neuromodulatory Action of Picomolar Extracellular A $\beta 42$ Oligomers on Presynaptic and Postsynaptic Mechanisms Underlying Synaptic Function and Memory. J. Neurosci. 2019, 39, 5986-6000. [CrossRef] [PubMed]

182. Novo, M.; Freire, S.; Al-Soufi, W. Critical aggregation concentration for the formation of early Amyloid- $\beta$ (1-42) oligomers. Sci. Rep. 2018, 8, 1783. [CrossRef] [PubMed]

183. Chen, X.-Q.; Mobley, W.C. Alzheimer Disease Pathogenesis: Insights From Molecular and Cellular Biology Studies of Oligomeric A $\beta$ and Tau Species. Front. Neurosci. 2019, 13, 659. [CrossRef] [PubMed]

184. Sakono, M.; Zako, T. Amyloid oligomers: Formation and toxicity of Abeta oligomers. FEBS J. 2010, 277, 1348-1358. [CrossRef] [PubMed]

185. Boland, B.; Yu, W.H.; Corti, O.; Mollereau, B.; Henriques, A.; Bezard, E.; Pastores, G.M.; Rubinsztein, D.C.; Nixon, R.A.; Duchen, M.R.; et al. Promoting the clearance of neurotoxic proteins in neurodegenerative disorders of ageing. Nat. Rev. Drug Discov. 2018, 17, 660-688. [CrossRef]

186. Nixon, R.A. Amyloid precursor protein and endosomal-lysosomal dysfunction in Alzheimer's disease: Inseparable partners in a multifactorial disease. FASEB J. 2017, 31, 2729-2743. [CrossRef]

187. Chakravorty, A.; Jetto, C.T.; Manjithaya, R. Dysfunctional Mitochondria and Mitophagy as Drivers of Alzheimer's Disease Pathogenesis. Front. Aging Neurosci. 2019, 11, 311. [CrossRef]

188. Mroczko, B.; Groblewska, M.; Litman-Zawadzka, A. The Role of Protein Misfolding and Tau Oligomers (TauOs) in Alzheimer's Disease (AD). Int. J. Mol. Sci. 2019, 20, 4661. [CrossRef]

189. Goedert, M.; Spillantini, M.G.; Jakes, R.; Rutherford, D.; Crowther, R.A. Multiple isoforms of human microtubule-associated protein tau: Sequences and localization in neurofibrillary tangles of Alzheimer's disease. Neuron 1989, 3, 519-526. [CrossRef]

190. Dixit, R.; Ross, J.L.; Goldman, Y.E.; Holzbaur, E.L.F. Differential regulation of dynein and kinesin motor proteins by tau. Science 2008, 319, 1086-1089. [CrossRef]

191. Dubey, M.; Chaudhury, P.; Kabiru, H.; Shea, T.B. Tau inhibits anterograde axonal transport and perturbs stability in growing axonal neurites in part by displacing kinesin cargo: Neurofilaments attenuate tau-mediated neurite instability. Cell Motil. Cytoskeleton 2008, 65, 89-99. [CrossRef] [PubMed]

192. Ittner, A.; Ittner, L.M. Dendritic Tau in Alzheimer's Disease. Neuron 2018, 99, 13-27. [CrossRef] [PubMed] 
193. Violet, M.; Delattre, L.; Tardivel, M.; Sultan, A.; Chauderlier, A.; Caillierez, R.; Talahari, S.; Nesslany, F.; Lefebvre, B.; Bonnefoy, E.; et al. A major role for Tau in neuronal DNA and RNA protection in vivo under physiological and hyperthermic conditions. Front. Cell. Neurosci. 2014, 8, 84. [CrossRef] [PubMed]

194. Marciniak, E.; Leboucher, A.; Caron, E.; Ahmed, T.; Tailleux, A.; Dumont, J.; Issad, T.; Gerhardt, E.; Pagesy, P.; Vileno, M.; et al. Tau deletion promotes brain insulin resistance. J. Exp. Med. 2017, 214, 2257-2269. [CrossRef] [PubMed]

195. Alonso, A.; Zaidi, T.; Novak, M.; Grundke-Iqbal, I.; Iqbal, K. Hyperphosphorylation induces self-assembly of tau into tangles of paired helical filaments/straight filaments. Proc. Natl. Acad. Sci. USA 2001, 98, 6923-6928. [CrossRef]

196. Tai, H.-C.; Wang, B.Y.; Serrano-Pozo, A.; Frosch, M.P.; Spires-Jones, T.L.; Hyman, B.T. Frequent and symmetric deposition of misfolded tau oligomers within presynaptic and postsynaptic terminals in Alzheimer's disease. Acta Neuropathol. Commun. 2014, 2, 146. [CrossRef] [PubMed]

197. Sevigny, J.; Chiao, P.; Bussière, T.; Weinreb, P.H.; Williams, L.; Maier, M.; Dunstan, R.; Salloway, S.; Chen, T.; Ling, Y.; et al. The antibody aducanumab reduces A $\beta$ plaques in Alzheimer's disease. Nature 2016, 537, 50-56. [CrossRef]

198. Klein, G.; Delmar, P.; Voyle, N.; Rehal, S.; Hofmann, C.; Abi-Saab, D.; Andjelkovic, M.; Ristic, S.; Wang, G.; Bateman, R.; et al. Gantenerumab reduces amyloid- $\beta$ plaques in patients with prodromal to moderate Alzheimer's disease: A PET substudy interim analysis. Alzheimers. Res. Ther. 2019, 11, 101. [CrossRef]

199. Zhao, X.; Rebeck, G.W.; Hoe, H.-S.; Andrews, P.M. Tarenflurbil protection from cytotoxicity is associated with an upregulation of neurotrophins. J. Alzheimers. Dis. 2008, 15, 397-407. [CrossRef]

200. Green, R.C.; Schneider, L.S.; Amato, D.A.; Beelen, A.P.; Wilcock, G.; Swabb, E.A.; Zavitz, K.H.; Tarenflurbil Phase 3 Study Group. Effect of tarenflurbil on cognitive decline and activities of daily living in patients with mild Alzheimer disease: A randomized controlled trial. JAMA 2009, 302, 2557-2564. [CrossRef]

201. Van Bulck, M.; Sierra-Magro, A.; Alarcon-Gil, J.; Perez-Castillo, A.; Morales-Garcia, J.A. Novel Approaches for the Treatment of Alzheimer's and Parkinson's Disease. Int. J. Mol. Sci. 2019, 20, E719. [CrossRef] [PubMed]

(C) 2020 by the authors. Licensee MDPI, Basel, Switzerland. This article is an open access article distributed under the terms and conditions of the Creative Commons Attribution (CC BY) license (http://creativecommons.org/licenses/by/4.0/). 